\title{
Organ-Specific Endothelial Cell Differentiation and Impact of Microenvironmental Cues on Endothelial Heterogeneity
}

\author{
Laia Gifre-Renom $^{1}\left(\mathbb{D}\right.$, Margo Daems $^{1}{ }^{(\mathbb{D}}$, Aernout Luttun ${ }^{1}$ (D) and Elizabeth A. V. Jones ${ }^{1,2, *(D)}$ \\ 1 Centre for Molecular and Vascular Biology, Department of Cardiovascular Sciences, \\ Katholieke Universiteit Leuven (KU Leuven), BE-3000 Leuven, Belgium; \\ laia.gifrerenom@kuleuven.be (L.G.-R.); margo.daems@kuleuven.be (M.D.); \\ aernout.luttun@kuleuven.be (A.L.) \\ 2 Department of Cardiology, CARIM School for Cardiovascular Diseases, Maastricht University, \\ 6229 ER Maastricht, The Netherlands \\ * Correspondence: liz.jones@kuleuven.be
}

Citation: Gifre-Renom, L; Daems, M.; Luttun, A.; Jones, E.A.V. Organ-Specific Endothelial Cell Differentiation and Impact of Microenvironmental Cues on Endothelial Heterogeneity. Int. J. Mol. Sci. 2022, 23, 1477. https://doi.org/ $10.3390 /$ ijms 23031477

Academic Editor: Béatrice Charreau

Received: 31 December 2021

Accepted: 19 January 2022

Published: 27 January 2022

Publisher's Note: MDPI stays neutral with regard to jurisdictional claims in published maps and institutional affiliations.

Copyright: (c) 2022 by the authors. Licensee MDPI, Basel, Switzerland. This article is an open access article distributed under the terms and conditions of the Creative Commons Attribution (CC BY) license (https:// creativecommons.org/licenses/by/ $4.0 /)$.

\begin{abstract}
Endothelial cells throughout the body are heterogeneous, and this is tightly linked to the specific functions of organs and tissues. Heterogeneity is already determined from development onwards and ranges from arterial/venous specification to microvascular fate determination in organ-specific differentiation. Acknowledging the different phenotypes of endothelial cells and the implications of this diversity is key for the development of more specialized tissue engineering and vascular repair approaches. However, although novel technologies in transcriptomics and proteomics are facilitating the unraveling of vascular bed-specific endothelial cell signatures, still much research is based on the use of insufficiently specialized endothelial cells. Endothelial cells are not only heterogeneous, but their specialized phenotypes are also dynamic and adapt to changes in their microenvironment. During the last decades, strong collaborations between molecular biology, mechanobiology, and computational disciplines have led to a better understanding of how endothelial cells are modulated by their mechanical and biochemical contexts. Yet, because of the use of insufficiently specialized endothelial cells, there is still a huge lack of knowledge in how tissue-specific biomechanical factors determine organ-specific phenotypes. With this review, we want to put the focus on how organ-specific endothelial cell signatures are determined from development onwards and conditioned by their microenvironments during adulthood. We discuss the latest research performed on endothelial cells, pointing out the important implications of mimicking tissue-specific biomechanical cues in culture.
\end{abstract}

Keywords: endothelial cell; vascular development; heterogeneity; organ-specific signature; phenotypic drift; microenvironment; mechanobiology; extracellular matrix

\section{Introduction}

Vascular endothelial cells line the entire circulatory system and show remarkable heterogeneity. Even though endothelial cells originate from the same progenitor cells during development, they eventually contribute to different subtypes of endothelia. Based on morphology, the microvasculature consists of three main phenotypes: discontinuous, fenestrated, and non-fenestrated endothelium (Figure 1). These morphological differences correlate with vascular permeability and contribute to organ-specific functions. Nonfenestrated endothelium has a low permeability, which is found in brain, heart, and lung microvessels, as well as within all larger vessels (i.e., arteries and veins). A fenestrated endothelium has transcellular pores of about $70 \mathrm{~nm}$ in diameter [1], which are covered by a thin, non-membranous diaphragm. As fenestrae are associated with increased filtration and trans-endothelial transport functions, they are found in kidney, endocrine glands, and gastric and intestinal mucosa. Lastly, discontinuous endothelium is found exclusively in sinusoidal endothelium, such as the bone marrow, the spleen, and the liver endothelium. 
The latter has larger fenestrations, up to 100 or $200 \mathrm{~nm}$ in diameter, that are devoid of a diaphragm and have large pores within individual cells [1]. Additionally, the underlying basement membrane is only partly developed, resulting in a high permeability. Each organ is made up of different types of endothelia. In the kidney, fenestrated endothelium in the peritubular capillaries and glomeruli ensures proper filtration, while continuous endothelium elsewhere provides the kidney itself with nutrients and oxygen [2]. Similarly, circumventricular organs of the brain are lined with fenestrated endothelium, while elsewhere, the tight blood-brain barrier (BBB) is found [3].

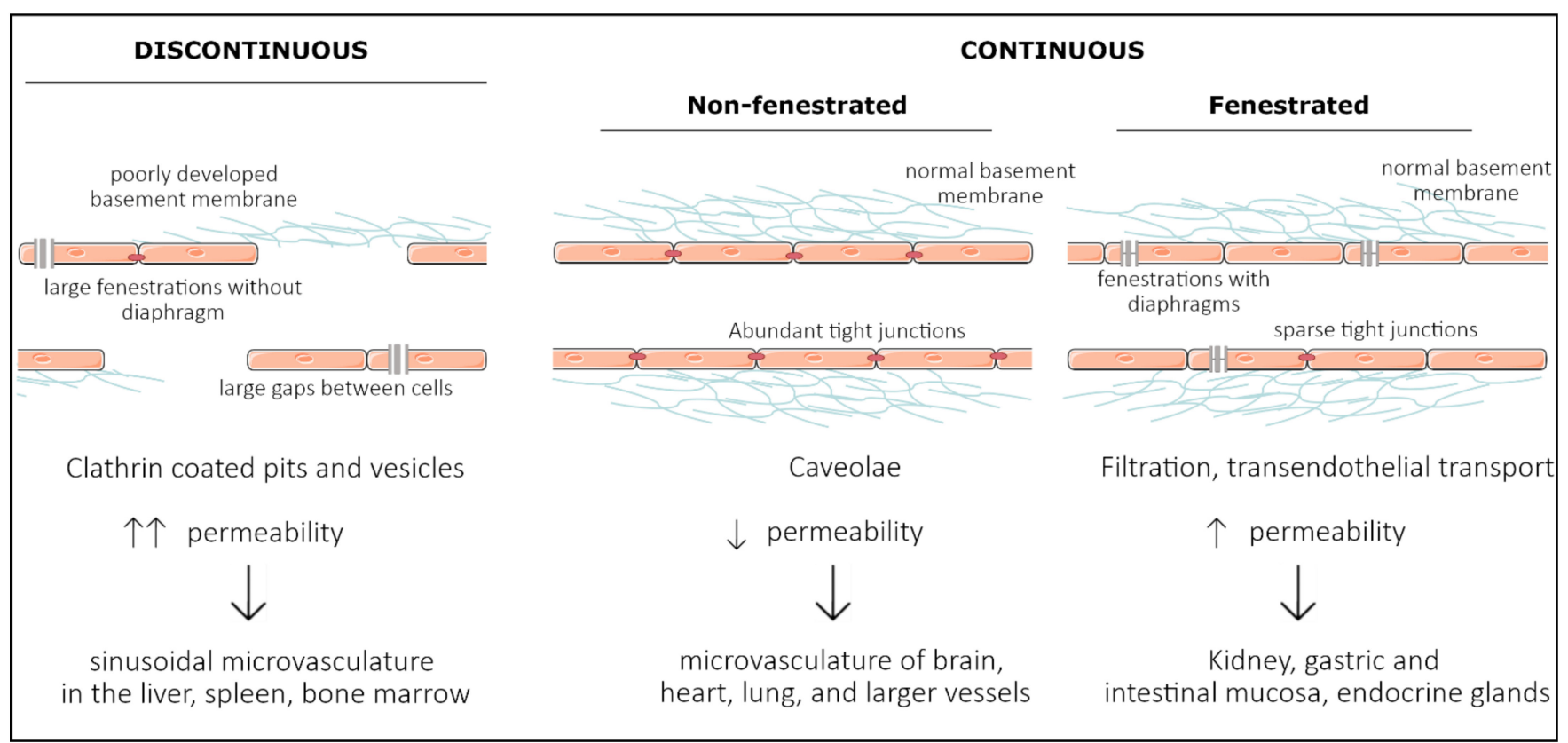

Figure 1. Representation of the three main structural phenotypes in organ-specific microvasculature. Discontinuous endothelium is mainly found in the sinusoidal microvasculature of the liver, spleen and in bone marrow, and is characterized by large fenestrations and pores within and in between endothelial cells, respectively. It has a poorly developed basement membrane and contains clathrin-coated pits and vesicles that dramatically increase permeability. Non-fenestrated endothelium is characterized by low permeability and a high abundance of tight junctions and caveolae. It is mostly found in the microvasculature of the brain, heart, and lung and in larger vessels. Fenestrated endothelium has an intermediate permeability and is characterized by fenestrations covered with a diaphragm. These fenestrations and sparse tight junctions ensure proper filtration and transendothelial transport, as found in the microvasculature of kidney, gastric and intestinal mucosa, and endocrine glands.

The endothelium is equipped with structural components involved in endocytosis, transcytosis, and proper cell-cell and cell-cytoskeleton contact. The presence of these structural components differs greatly between organ systems. While the BBB is extremely enriched with tight junctions, they gradually become looser when moving from large arteries towards the capillaries. However, in post-capillary venules, tight junctions are rather disorganized, facilitating the inflammation-induced extravasation of leukocytes [4]. Furthermore, the liver sinusoidal endothelium is equipped with high amounts of clathrincoated pits and vesicles that aid in endocytosis [5]. Similarly, caveolae are most abundant in continuous, non-fenestrated capillaries, such as heart and lung tissue, while they rarely appear in the BBB, as they ensure proper transcytosis across the endothelium. These characteristics affect vascular permeability and heterogeneity across organs.

Endothelial heterogeneity is induced and maintained by the surrounding microenvironment, which is already present during embryonic development. In the adult organism, endothelial cells are influenced by both mechanical and biochemical cues derived from 
the tissue. Examples of these cues are the composition of the basement membrane, tissue stiffnesses, blood flow rates, pulsatility, and the close contact with their neighboring cells, such as cardiomyocytes in the heart or astroglial cells in the brain. However, these are all nonheritable changes that result in transcription factor-induced gene expression and posttranslational modifications. Endothelial heterogeneity is also regulated by epigenetic modifications, which are preserved during mitosis and in the absence of extracellular cues. Although endothelial cells quickly lose their organ-specific properties when cultured [6,7], several DNA microarray studies revealed site-specific signatures that remain after several passages, demonstrating the importance of epigenetics for endothelial heterogeneity [8,9].

There has been a great effort in understanding endothelial heterogeneity as researchers attempt to mimic these specific types of endothelia in vitro. Understanding how endothelial cells acquire and maintain their heterogeneity will allow us to move towards more specialized vascular research and an organ-oriented treatment strategy. In this review, we discuss how endothelial cell heterogeneity is determined during development and adulthood, as well as the recent advances in the study and characterization of organ-specific endothelial cell signatures. We also raise awareness on the importance of implementing microenvironmental cues in vascular research in order to obtain more relevant and organ-specific readouts towards more specialized tissue engineering approaches.

\section{Development of Organ Specificity among Endothelial Cells}

\subsection{Vasculogenesis-Intrinsic Versus Extrinsic Factors}

Endothelial cells have a mesodermal origin; during vasculogenesis, a "first draft" of the vascular system is laid down to support the growing embryo [10]. In vertebrates, vasculogenesis is initiated in the blood islands at the distal aspect of the yolk sac. The blood islands give rise to both primitive endothelial cells, called angioblasts, and primitive red blood cells, erythroblasts [11,12] (Figure 2). Extraembryonic angioblasts subsequently migrate over the yolk sac to form a randomly organized primitive vascular plexus. VEGF signaling is abundantly studied as a critical mediator of vasculogenesis [13-16]. Both heterozygous and homozygous $V e g f-A$ null mice died during embryonic development, at E11.5 and E9.5, respectively, due to impaired angiogenesis and disrupted formation of the blood islands $[13,14]$. Similarly, Vegfr $2^{-/}$embryos die between E8.5 and E9.5 due to defects in vasculogenesis and the lack of blood islands [15]. Vasculogenesis is tightly regulated by a family of E26 transformation-specific (ETS) transcription factors [17].

Although a certain redundancy has been described, ETV2 drives both Vegfr2 and Tie2 expression in endothelial progenitor cells $[18,19]$. Already at E8.5, Etv2 ${ }^{-/-}$embryos present with impaired vasculogenesis and reduced VEGFR2 expression, while they die between E9.0 and E10.5 [18,19]. Although VEGF signaling drives endothelial development, its own expression is regulated by the microenvironment of the developing tissue. In lung tissue, VEGF is initially secreted by mesenchymal cells, while later, the main source shifts to alveolar epithelium [20-22]. Between E9.5 and E12, a balance between FGF9 expressed by epithelial cells and FGF10 expressed by the surrounding mesenchymal cells sustains VEGF expression. FGF10 drives mTORC1/Sprouty2 signaling in epithelial cells, which initiates the production of VEGF by the epithelium [23]. In turn, FGF9 binds FGFR1 on epithelial cells and induces the expression of VEGF [24]. Similarly, in the developing heart, cardiomyocytes are an important source of VEGF for the coronary vessels; embryos with a cardiomyocyte-specific Vegf ablation present with fewer coronary vessels and a thinned ventricular wall at E13.5, suggesting that the tissue-specific microenvironment regulates endothelial differentiation by regulating VEGF expression [25]. Furthermore, endothelial differentiation is at least partly driven by FGF2 and BMP4, although they are classically needed to induce the mesoderm. Loss of BMP4, as well as downstream effectors SMAD5 and SMAD4, prevents the induction of mesoderm and as a result, these embryos lack an organized yolk sac vasculature [26-29]. Moreover, BMP4 alone is sufficient to induce endothelial formation in the absence of endodermal cues, suggesting that BMP4 drives mesodermal formation [30]. However, vasculogenesis alone does not ensure that the 
vasculature expands, remodels, and adapts according to the requirements of the developing embryo. During development and throughout adult life, new blood vessels are created from the existing vasculature during either sprouting angiogenesis or intussusceptive angiogenesis [31].

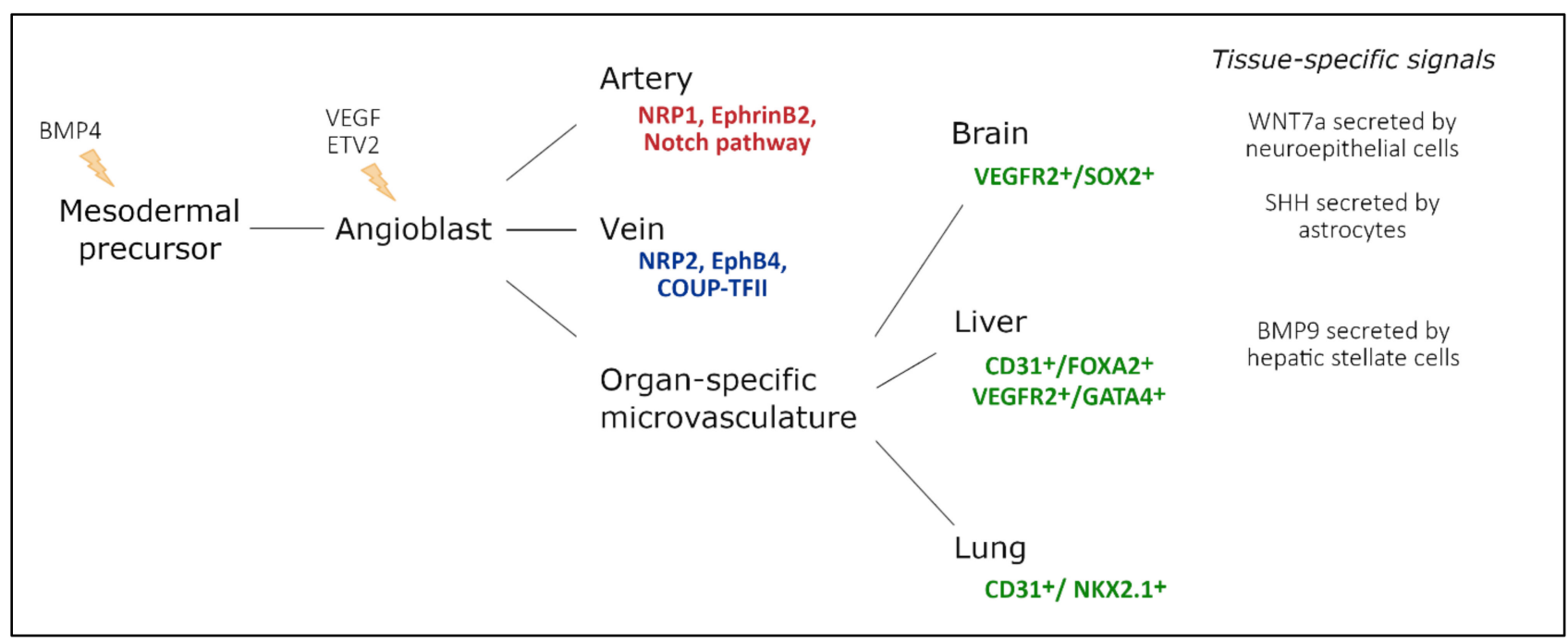

Figure 2. Endothelial cell heterogeneity throughout embryonic development and main factors involved. Mesodermal cells differentiate into vascular and hematopoietic progenitors under the influence of BMP4, secreted by the endoderm. These endothelial progenitor cells differentiate under the influence of VEGF-signaling, driven by ETV2 expression. In turn, they populate arteries, veins, and capillaries. During arteriovenous differentiation, endothelial cells take on an arterial or venous identity, characterized by expression of Nrp1, EphrinB2, and Notch signaling components, or Nrp2, EphB4, and Coup-TFII expression, respectively. Endothelial cells from capillaries are influenced by the microenvironment of their respective organ. Furthermore, a subset of organ-specific endothelial cells also has non-mesodermal origins, based on co-expression of endothelial markers and tissue-specific endoderm markers. Adapted from [32].

\subsection{Large Conduit Vessel Differentiation}

Although all endothelial cells originate from the same type of progenitor cell, there is a big discrepancy between large conduit vessels (arteries or veins) and the microvasculature. After the onset of blood flow, the primitive vascular plexus is remodeled into a hierarchical network, including arteries, veins, and capillaries. Although the heart tube already beats by E8.0, proper blood flow is only present once erythrocytes are released from the blood islands at E8.5, with vascular remodeling occurring over the following day $[33,34]$. In the absence of erythrocytes or blood flow altogether, the primitive plexus fails to remodel into differentiated arteries and veins [33,35]. Moreover, restoring blood viscosity by injecting hetastarch intravascularly in embryos lacking erythrocytes is sufficient to rescue vascular remodeling, highlighting the crucial role of mechanical forces in creating a proper vascular hierarchy [33].

Arterial and venous differentiation is the earliest demonstration of endothelial heterogeneity in the embryo [8]. It is present before the onset of flow [36]; however, shear stress can override this initial identity. Ligation of vitelline arteries in chicken embryos results in a venularization within $24 \mathrm{~h}$, as evidenced by downregulation of Gja5, Nrp1, and EphrinB2 and upregulation of Coup-TFII, Nrp2, and Tie2 [35,37]. Strikingly, reperfusion completely restores the initial arterial gene expression, which highlights the plasticity of endothelial identity and the importance of shear stress for arteriovenous differentiation [35,37]. 


\subsection{Organ-Specific Vascular Development}

As organogenesis commences and tissues specialize into organs with specific morphologies and phenotypes, endothelial cells are no longer exclusively influenced by intrinsic factors. Along embryonic development, newly formed endothelial cells are exposed to extrinsic factors that induce a tissue-specific endothelial differentiation program (Figure 2).

Within the developing brain, WNT7a/b secreted by the neuroepithelial cells binds endothelial WNT receptors Frizzled 4/6/8 and stabilizes $\beta$-catenin (encoded by Ctnnb1). Neuroepithelial-specific loss of WNT7a/b signaling induces severe hemorrhages within the central nervous system (CNS) exclusively, demonstrating that the neural microenvironment influences the surrounding vasculature [38]. Endothelial-specific $\mathrm{Ctnnb1}^{-/-}$and Lrp $5 / 6^{-/-}$embryos present with a similar phenotype, while the neural tissue completely lacks endothelial cells when endothelial $\beta$-catenin is destabilized [39,40]. WNT signaling is thought to drive a specific CNS endothelial differentiation program, including the expression of typical membrane receptor and transporter GLUT1. Impaired WNT7a/b signaling directly reduces GLUT1 expression levels in neural endothelial cells, while ectopic WNT7a drives GLUT1 expression in endothelial cells outside of the CNS [38]. Moreover, in the absence of $C t n n b 1$, the expression of several typical transcription factors declines in neuronal endothelial cells, demonstrating a key role for $\beta$-catenin in activating a BBB-specific differentiation [41].

In contrast to WNT signaling, the effects of GPR124 signaling are confined to specific regions of the developing CNS [42,43]. GPR124 is thought to regulate endothelial cell sprouting and migration in the forebrain and spinal cord exclusively. Gpr $124^{-/}$embryos show reduced sprouting in the forebrain region and vascular patterning defects by E11.5 and die by E15.5 [42,43]. GLUT1 expression in the forebrain is reduced in Gpr124 ${ }^{-1-}$ embryos, demonstrating that the acquisition of BBB markers may be coupled to developmental brain angiogenesis [42]. Furthermore, sonic hedgehog $(\mathrm{SHH})$ is secreted by perivascular astrocytes and regulates the expression of several tight junction proteins, including Occludin, VE-cadherin, Claudin3, and Claudin5 [44]. Similarly, endothelial-specific loss of Smoothened (Smo), a downstream target of SHH signaling, results in an increased BBB permeability at E14, accompanied by a decreased expression of Occludin, Claudin3, Claudin5, and ZO1 [44].

In the liver, GATA4 has been identified as an important regulator of liver sinusoidal endothelial cell (LSEC) specification [45]. Deleting Gata4 in STAB2 ${ }^{+}$or LYVE1 ${ }^{+}$cells results in embryonic lethality between E15.5 and E17.5, while a severely hypoplastic liver is observed at E11.5. LSEC-specific Gata4 ${ }^{-/-}$embryos undergo a major switch from a sinusoidal phenotype to a continuous capillary phenotype, accompanied by the formation of a basement membrane [45]. Furthermore, endothelial VE-Cadherin is upregulated in LSEC-specific Gata $4^{-/-}$embryos, demonstrating an increased stability of adherens junctions in the liver microvasculature. Recently, BMP9, secreted by hepatic stellate cells that ensheath the liver sinusoids, was identified as one of the paracrine regulators of LSEC fenestration by regulating GATA4 expression in LSECs [46].

Although endothelial cells generally have a mesodermal origin, a subset seems to be derived from tissue-specific endodermal cells. Between E10.5 and E14, a subset of VEGFR2 ${ }^{+} / \mathrm{SOX}^{+}$endothelial cells is observed within the developing brain, which is lost by E18.5 [47]. Similarly, at E9.5, some rare $\mathrm{CD} 1^{+} \mathrm{FOXA2}^{+}$cells are observed in the liver buds; however, by E12.5, they evolve into an evenly dispersed population of $\mathrm{CD} 31^{+} \mathrm{FOXA2}{ }^{+}$ cells [48]. Furthermore, a subset of GATA $4^{+} /$VEGFR2 ${ }^{+}$double-positive cells has been identified between E10.5 and E14 in the budding liver, suggesting a common progenitor cell with hepatocytes [47]. Single-cell analysis of the developing liver predicted that also DLL4, VEGFA, and the TGF- $\beta$ signaling pathway affect LSEC identity, regulating, amongst others, the expression of Icam2, Sparc, and Lyve1 [49].

Within the lung, a subset of endothelial cells is thought to derive from NKX2.1 $1^{+}$ endodermal cells [50]. Already at E10.5, a subset of endothelial cells in the lung co-expresses CD31 and NKX2.1, which is lost by E18.5 [47]. NKX2.1-specific Vegfr2 ${ }^{--}$embryos present 
with a decreased endothelial population [47]. Thus, it seems that a subset of endothelial cells is derived from a similar progenitor type as their surrounding tissue, committing to the vascular lineage over the course of development.

\section{Technological Progress in Assessing Endothelial Cell Heterogeneity}

Independent of which vascular bed or organ they reside in, each endothelial cell's specific features are dictated by a unique panel of molecular determinants which translate into characteristic morphological hallmarks that accommodate the specific functions of the host organs $[32,51,52]$. Rather than giving an extensive overview of the current knowledge of specific molecular, morphological and functional features of endothelial cells in different organs (for which we refer to a selection of seminal and recent reviews) [32,51-58], we use the liver endothelium to demonstrate how rapid technological advances have revolutionized the field of endothelial cell heterogeneity and have caused an exponential rise in the number of reports on this topic in the literature (Figure 3).

The earliest studies documenting heterogeneity among endothelial cells were from the 1950 's and mostly focused on particular morphological features that could be visualized at subcellular resolution by transmission electron microscopy [32,59]. The presence of nondiaphragmed fenestrae in LSECs, possibly the most prototypic hallmark of specialization in endothelial cells, was first described by Eddie Wisse in 1970 (Figure 3A) [60]. Another elegant technique to depict the organ-specific structural organization of (micro)vascular endothelial cell networks in different organs is vascular casting combined with scanning electron microscopy or micro-computed tomography. This combination shows how the sinusoidal vessels bridge several portal venules with a central venule within the liver lobule, the functional unit of the liver (Figure 3A) [61-63]. The same technology has been recently used to reveal that expansion of the sinusoidal network in the liver can occur through a less common blood vessel formation modus, i.e., intussusceptive angiogenesis [64]. Specific posttranslational protein modifications, such as glycosylation, can also be used to identify heterogeneity, such as by differential binding of natural glycan ligands, i.e., lectins (Figure 3B) [65]. Together with the larger size and lower frequency of fenestrae, the preferential ability of periportal LSECs to bind certain lectins represented the first evidence for zonal differences in LSEC characteristics [65-67].

Later on, the sequencing of the entire genome of several species, including humans, and the development of protocols to isolate endothelial cells from different tissues enabled genome-wide expression profiling at the RNA level of these cells. There has been an impressive evolution in this area on different levels. First, the earliest studies establishing differential genome-wide expression profiles of organ-derived endothelial cells used a bulk approach. This consisted in profiling by sequential analysis of gene expression (SAGE) [66], microarray [58,68-70] or (later) by RNA sequencing (recently archived in EndoDB, an elaborate database of endothelial transcriptomics) [71] on all endothelial cells of an organ isolated by 'pan-endothelial' markers (e.g., PECAM1, VE-cadherin or Tie2; Figure 3B). Two important caveats, however, are that the literature is not always unequivocal in terms of the expression of certain markers $[59,72,73]$, and that species-specific differences have been reported, e.g., in the case of plasmalemmal vesicle-1 (PV-1 or PLVAP), which is present on adult mouse but not human LSECs $[64,73,74]$, or in the different expression levels of selenoprotein between human and pig HUVECs [75]. Similarly, functional differences between mouse and human lung microvascular endothelial cells have been reported, including differences in microfilament alignment and barrier permeability in response to inflammatory conditions [76]. As new therapeutics are traditionally developed in animal models prior to clinical testing, these species-specific differences must be considered during their translation to patients. 

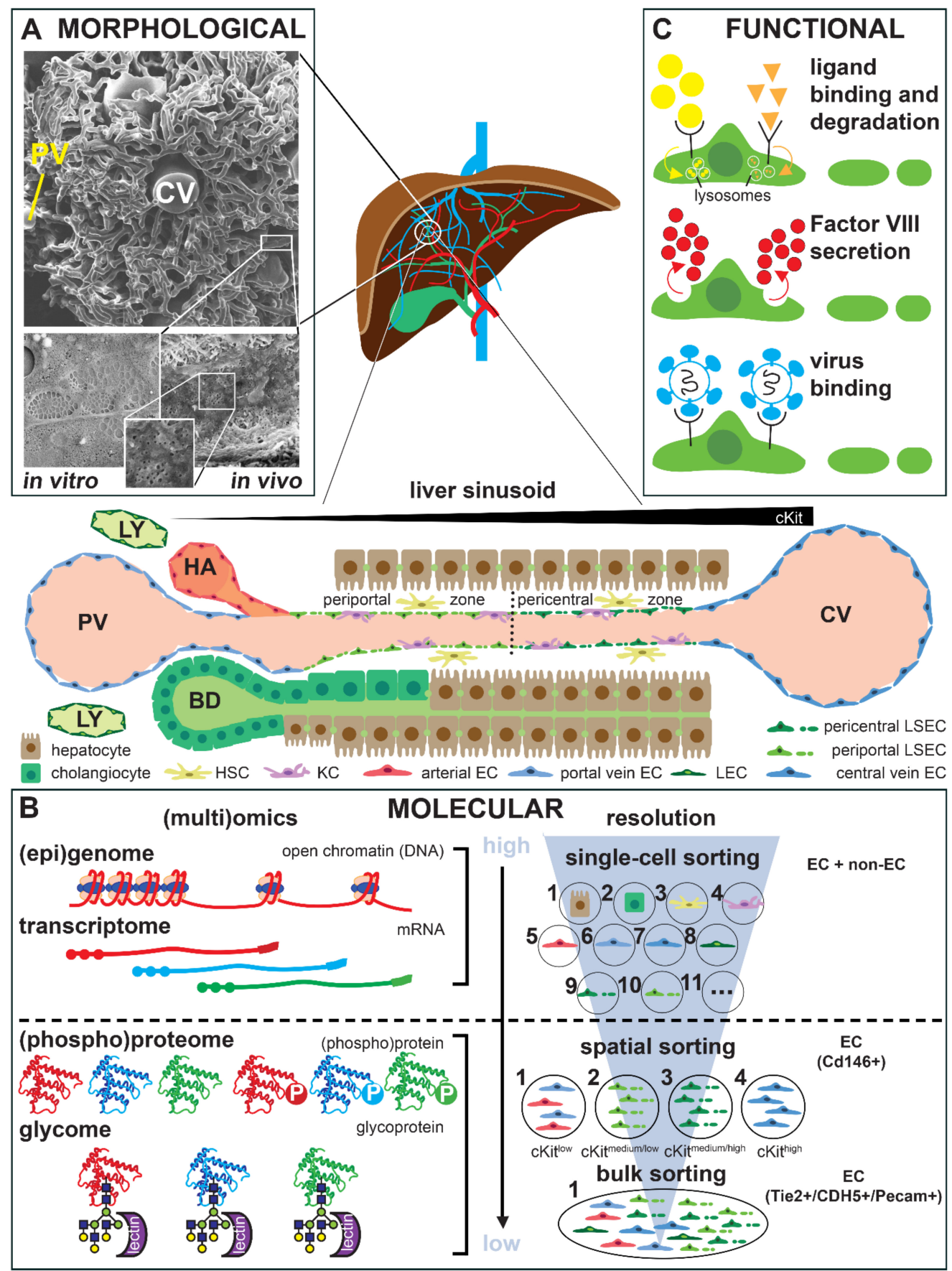

Figure 3. Morphological, molecular, and functional characterization of liver endothelial cells. Central panel. Schematic representation of a liver sinusoid with the different cell types and the zonated organization of the liver sinusoidal endothelium. Note the increasing gradient of cKit expression from the portal nodules to the central venule. HA: hepatic arteriole; BD: bile duct; PV: portal venule; CV: central venule; LY: lymphatic capillaries. (A) Morphological characterization of the liver lobular vasculature (top), liver sinusoids (bottom, right) and freshly isolated liver sinusoidal endothelial cells (LSECs; bottom, left) by scanning electron microscopy revealing fenestrae organized in sieve plates. (B) Molecular characterization of liver endothelial cells at different omics levels (left) and at different cellular resolutions (right). The dotted line indicates that single-cell resolution is currently routinely possible for the epigenome and the transcriptome, but not (yet) for the (phospho)proteome or glycome. The glycome can be analyzed indirectly by specific lectin binding patterns. P: phosphate. (C) Functional characterization of LSECs showing three commonly used assays, i.e., ligand binding and lysosomal degradation (top), Factor VIII secretion (middle), and virus binding (bottom). 
More recently, by changing the resolution of transcriptomic profiling to the single-cell level (scRNAseq; recently reviewed for the vascular system in general in ref. [53] and the liver in particular in ref. [77]), it has become clear that endothelial cell heterogeneity does not stop at the boundaries of different organs but that there is a significant level of intra-organ heterogeneity [78,79]. In the case of the liver, the earlier mentioned zonal differences seen in the sinusoidal endothelium by morphological and histological analyses were confirmed at the transcriptional level by scRNAseq (Figure 3B) [74,80-83]. Importantly, since scRNAseq can simultaneously document the expression profile of all cells in an organ, the reciprocal communication between endothelial and non- endothelial cells that co-determines their specific characteristics can also be analyzed [55,74,83,84]. Furthermore, this technology also allows for the detection of alterations in the cellular landscape, where certain endothelial cell subtypes may expand, newly arise, or disappear only upon pathological challenges $[74,85,86]$. For instance, it has been shown that the liver lymphatic endothelial cell population significantly expands after a fibrotic challenge [85,87].

One important drawback of scRNAseq, caused by the necessity to (enzymatically) dissociate the tissue of interest, is the potential differential sensitivity of cell types (including endothelial cell types) to the dissociation protocol, causing loss of these cell types in the analysis [88-90]. Single-nuclei RNA sequencing (snRNAseq) can overcome this dissociation bias as the nuclear membrane seems more resistant to tissue dissociation than the cell membrane. Furthermore, since nuclei, unlike cells, also are resistant to freeze-thaw manipulation, snRNAseq can also be performed on frozen archived material. While multiple studies using snRNAseq have been reported on the heart [91], only two studies using snRNAseq on the liver have been reported to our knowledge [92,93].

Another gap in scRNAseq is that spatial information is lost. Spatial transcriptomics has been recently developed to overcome this problem, although the resolution of this technology may not (yet) be sufficient to allow for analysis at a single-cell level [94]. In a recent study, Hou et al. have integrated spatial transcriptomics with scRNAseq to reveal the in situ expression profile of the developing human liver [95]. Alternatively, in the liver, spatial information related to LSEC zonation has been delivered by paired-cell sequencing, thereby using the zonated hepatocyte expression pattern as a landmark or by spatial sorting based on markers previously shown to have a zonated endothelial expression pattern, such as cKit (Figure 3B) [81,96].

A second revolution in the 'omics area' is the departure from a 'transcriptomics-centric' view through combining/cumulating different 'omics' analyses, such that information is obtained not only on the transcriptome, but also on the proteome and the epigenome (Figure 3B) [92,93,96-103]. At this time, however, single-cell analyses at the level of proteins and their post-translationally modified versions remain a technical challenge. As referred to above, in a recent study, to overcome this problem, Inverso et al. have designed an unprecedented method based on spatial sorting in order to enable zonated multiomics analyses of liver endothelial subclusters defined by scRNAseq [96]. Using this method, they created a multiomic map of the liver lobular vasculature (which is available as an interactive web tool) and identified a zonated protein activation (phosphorylation) pattern, including for tyrosine kinase Tie1, which regulates zonation through Wnt-signaling. While proteomic analyses are still beyond single-cell resolution [104], analysis of the epigenetic status at single-cell resolution is already possible by single-cell assay for transposaseaccessible chromatin using sequencing (scATACseq; Figure 3B) [99,102,103]. Integrating transcriptomic data (scRNAseq) with information on chromatin accessibility (scATACseq) allows for the unraveling of gene regulatory networks ('regulomes') governing cellular heterogeneity [105]. In the liver, this integration has been recently applied to document functional heterogeneity among hepatocytes, but non-parenchymal cells (like endothelial cells) were not included in this study [102].

In addition to morphology and molecular expression, specialized functions are also part of the organ-specific endothelial cell signature $[32,57,106]$. In many cases this functional information can be derived by functional annotation analysis of the transcriptomic 
fingerprint $[68,69,78,80,82,87,102,106-108]$. The identified functions can then be tested. As for LSECs, (specific) functions that can be tested include (Figure 3C): (i) the binding, uptake and lysosomal degradation of fluorescently labeled macromolecules (reflecting the presence of scavenger receptors such as mannose receptor or MRC1, the Fc gamma receptor Ilb or Stabilins) [59,107,109-112], (ii) the binding of viral proteins (reflecting the expression of receptors interacting with these viruses such as L-SIGN) [107]; and (iii) the production of coagulation Factor VIII [110,113].

Alternatively, an organ-specific functioning of endothelial cells can be tested by their ability to support the function of the organ's parenchymal cells in co-culture models, e.g., albumin production by hepatocytes in the liver [106]. A recent study has shown that the artificial overexpression of LSEC-overrepresented transcription factors in non-specialized endothelial cells is not sufficient for a full restoration of the functional, morphological, and molecular hallmarks of LSECs, suggesting that additional extrinsic cues from the specific liver environment are also required [107].

One overall limitation of most current studies characterizing endothelial cell heterogeneity is that the analysis only takes a snapshot of the endothelial cell functional, molecular, and morphological passport. Thereby these do not account for the dynamic nature of endothelial cells, which can quickly alter their phenotype in response to their changing environment. Time-lapse technologies can be part of the solution. In the case of the liver, it has been shown that the fenestrae are very dynamic structures and that their size, (re)appearance, and position can be monitored on live cells by four-dimensional time-lapse atomic force microscopy [114].

\section{Organ-Specific Endothelial Cell Culture and Phenotypic Drift}

During the last decades, an important advance in the characterization of organ-specific endothelial transcriptional and functional signatures has revolutionized the field. Despite this, proficient use of organ-specific endothelial cells in vitro is still conditioned to the difficulties for maintaining those features in culture [115]. One of the main challenges in tissue engineering and regenerative medicine, for example, is to obtain functional and vascularized (or vascularizable) grafts and organoids suitable for implantation or as models for in vitro studies. Several vascularized organoids are being developed so far by combining parenchymal cells of specific organs and endothelial cells in culture [116]. Besides, cultures of endothelial cells in monolayers represent a critical tool in mechanobiology, especially for traction force analyses [117]. In all cases, researchers must decide what source of endothelial is the most suitable. As can be observed in Table 1, many of them use commercially available organ-specific endothelial cells [118-128] and only a few freshly isolate the endothelial cells they work with [106,129-132]. Others use human embryonic or pluripotent stem cells (hESCs or hPSCs), co-/differentiated into endothelial cells in the presence (or not) of other stromal cells (such as pericytes or smooth muscle cells) or organotypic parenchymal cells [133-135]. Another option is to genetically modify organ-specific endothelial cells after isolation to force them to maintain their phenotypical cues for the longer term $[124,125,136]$. Yet, many researchers still chose insufficiently specialized endothelial cells, such as human umbilical vein endothelial cells (HUVECs) [137-140].

These approaches all face two common limitations. First, the characterization of specialized endothelial cells is still emerging and, thus, incomplete. Naturally, endothelial cells in $2 \mathrm{D}$ cultures or in $3 \mathrm{D}$ /organoids are being routinely characterized to validate these as mature organ-specific endothelial cells. Nevertheless, and specifically pointing at the hESCderived endothelial cells, these mostly resemble the ones in embryonic developmental stages [134]. In this regard, Pappalardo et al. specifically observed how the maturity of human dermal blood endothelial cells stood out in the maintenance of vascularized skin grafts in the long term, compared with hPSC-derived endothelial cells and HUVECs [141]. The best way to determine the degree of validation for these endothelial cells would be to have the full genetic and phenotypic description of what each organ-specific endothelial cell should be like, but this knowledge is still limited. 
Alternatively, freshly isolated cells can be used as a control. Marcu et al. made a comparison between gene expression in human fetal heart, liver, lung, and kidney endothelial cells either freshly isolated or kept in culture over 2-5 passages. They identified that most of the differentially expressed genes between the two conditions were likely linked to the tissue microenvironment because these were not observed after in vitro culture, which decreased cell specialization [106]. For example, between heart and kidney, only 867 genes were differentially expressed after in vitro culture, whereas $>5000$ differentially expressed genes were identified in freshly isolated cells. This brings us to the second common limitation: after few passages, organ-specific endothelial cells lose many of their specific features if they do not meet their (not yet fully described) microenvironmental requirements. This phenomenon is known as phenotypic drift [9,142].

In an attempt to neutralize this loss, some groups have investigated the use of genetic modifications like an adenoviral genetic modification (transfection of E4ORF1) in primary endothelial cells (from lung and heart) to avoid cellular transformation along passages, preserving endothelial features in a longer-term [124,125]. Similarly, Palikuqi et al. transiently overexpressed the embryonic ETV2 factor in mature human endothelial cells in vitro (detailed in Table 1) and co-cultured these with organoid models (e.g., pancreatic islets), obtaining organ-specific endothelial cell cues [136]. However, the authors warn that their results may differ from those obtained by native endothelial cell counterparts [124,125]. The use of low specialized endothelial cells has become, therefore, one of the most suitable solutions to ensure a greater reproducibility in vascular research, even if such results have compromised specificity. Because of this, many studies are still based on the use of HUVECs (or other low specialized endothelial cells) as these are the best characterized endothelial cell types. Readouts from those are, regardless of the great heterogeneity in the endothelial cell population and its huge implications, generic. In brief, there is a profound need for reaching a comprehensive understanding of what features make organ-specific endothelial cells unique, and which of them can be rescued or maintained in culture through mimicking their microenvironmental cues.

\section{Role of the Tissue Microenvironment in Adult Endothelial Cell Heterogeneity}

The improved resolution in "-omics" by single-cell and single-nuclei screening technologies is providing a constantly expanding picture of the heterogeneity within the endothelial cell population, as reviewed in Section 3. Their phenotype repertoire is strongly linked to the high diversity of microenvironments to which these cells are exposed. Thus, besides describing their genetic and functional signatures, the different contexts that these specialized cells are experiencing the need to be considered to picture out what are the extrinsic factors modulating their unique phenotypes. Within their respective tissues, endothelial cells are exposed to mechanical forces, such as shear stress and circumferential stretch by the blood flow, tissue stiffness, or pulsatility, and to biochemical factors, such as basement membrane or (more broadly) extracellular matrix (ECM) composition, cell-cell interaction, paracrine signaling pathways [143], cytokines [144], and other metabolites. Only by understanding the factors involved in conditioning their phenotypes can we begin to learn how to maintain and use these cells in culture.

\subsection{Mechanical Cues Determining Endothelial Cell Heterogeneity}

The different mechanical cues with effects on endothelial cell behavior or morphology have been recently reviewed elsewhere [145], but little emphasis is placed on the organ-specific effects. Here, we compile and discuss what has been reported on the mechanobiology of the endothelial cells' heterogeneity.

\section{Organ-Specific Responses to Tissue Stiffness, Shear Stress, and Cellular Stretch}

We know that endothelial cells can sense and react according to the mechanical stimuli that they experience in specific tissues. Yet, what are the phenotype changes associated with a given mechanical stimulus? Or, in other words, what are the stimuli in specific tissues 
and organs that make endothelial cells specialize and become heterogeneous? With the rise of mechanobiology [146], new tools have been developed to mechanically characterize living tissues from the macroscale to a nanoscale range [147]. The tissue stiffnesses for the brain, liver, and heart, for example, have been reported to be $0.6-2.4 \mathrm{kPa}$ [148], $6 \mathrm{kPa}$ [149], and $25 \mathrm{kPa}$ on average [150], respectively. Thus, these measurements have facilitated the identification and comparison between different tissue (and cellular) stiffnesses under physiology and disease, as reviewed by Guimarães and colleagues [147]. For instance, tissue-specific stiffness was firstly reported to have an impact on cell lineage fate in 2006, when differently cross-linked polyacrylamide gels mimicking brain $(0.1-1 \mathrm{kPa})$, muscle $(8-17 \mathrm{kPa})$, and stiff matrices (25-40 kPa) proved to be neurogenic, myogenic or osteogenic, respectively, for naive mesenchymal stem cells [151]. Thereby, physiologically relevant tissue stiffnesses, as well as shear stresses, can nowadays be mimicked and applied in vitro to endothelial cells [128], composing more and more sophisticated models for mechanistic mechanotransduction and heterogeneity studies.

Endothelial cells are affected by changes in their microenvironment stiffness with functional implications that can lead to disease. For instance, LSECs lose their fenestrations and become fibrotic when cultured on stiff matrices [149], or fuse and enlarge their fenestrations when conditioned to increased shear stress levels [152]. This is known to be associated with an increase in the production of nitric oxide (NO) by LSECs under higher shear stress levels [153], favoring a quick adaptation to changes in perfusion without affecting functionality.

However, when livers are fibrotic (or stiffer), although their endothelial cells experience greater levels of shear stress due to the augmented tissue resistance, their NO synthase (NOS) levels do not increase as in healthy LSECs [154]. The rate of NO production in response to flow has been shown to be dependent on the ECM stiffness in (bovine) aortic endothelial cells [155]. For HUVECs and immortalized human microvascular endothelial cells, the effect of the subendothelial stiffness was also studied and compared [156]. Based on traction force microscopy assays and transcriptomics, both cell types responded with an increase in their traction forces on stiffer substrates. However, variations in stiffness did not have an important impact on the transcriptome of these cells, and only a few stiffnessdependent genes were differentially expressed (i.e., upregulated TGF- $\beta 2$ in HUVECs on stiffer matrices) [156].

Endothelial cells from different organs can behave differently under the same shear conditions. Under a 4 dynes $/ \mathrm{cm}^{2}$ laminar shear, mouse microvascular pulmonary endothelial cells increase their cell stiffness and align with the flow direction, whereas cardiac endothelial cells do not, unless arachidonic acid is added [124]. When exposed to softer matrices (500 kPa polydimethylsiloxane or PDMS) instead of the classic polystyrene (PS) slides (2-3 GPa), under flow ( 2 dynes $/ \mathrm{cm}^{2}$ ), cardiac endothelial cells showed more alignment on the stiffest substrate, whereas lung endothelial cells aligned and elongated more on the softer one [125]. However, although $500 \mathrm{kPa}$ is more close to physiological stiffnesses than $2 \mathrm{GPa}$, limited tissues reach such levels in healthy conditions (e.g., nerves, cartilage, ligaments, tendons, bones [147], and heart valve leaflets [157]). In those studies, moreover, cardiac and lung endothelial cells were transfected with the E4ORF1 of the AdE4 gene complex to promote long-term survival as differentiated endothelial cells. Thus, it is unclear whether their native microvascular counterparts would have behaved equally.

Under shear stresses up to 16 dynes $/ \mathrm{cm}^{2}$, brain microvascular endothelial cells neither aligned with the direction of flow, contrasting with HUVECs, that did so [120]. Reinitz et al. point out that this may be a BBB pre-programmed feature that would not be affected by shear stress. Yet, these cells were cultured directly on PS surfaces (2-3 GPa), very far from the brain native stiffness (1-3 kPa, [147]). It is known that mesenchymal stem cells grown on soft matrices elongate to a greater extent and form stronger junctions in response to flow than those grown on stiffer matrices [158]. However, how the soft nature of the brain may affect the specialization of brain endothelial cells is still poorly understood [159]. Studies on brain endothelial cells are mostly focused on the BBB permeability, drug delivery, 
and the development of in vitro BBB models [160]. Shear stress in the brain increases the expression of tight junction proteins as well as their tightness [118,161], but only a few have characterized the impact that stiffness may have in such models [162]. There is likely little success in them forming monolayers on soft matrices, as evidenced by the improvement in monolayer coverage after stiffening collagen I gels with genipin crosslinkage [135]. In addition, tissue stiffness has implications on the glycocalyx composition of brain endothelial cells. A drastic reduction in the expression of heparan sulfate and Glypican 1 in the glycocalyx of brain-derived endothelial cells was reported after cultures on glass or plastic, compared to 2.5 or $10 \mathrm{kPa}$ hydrogels [163].

Mechanical cues might facilitate the maintenance of structural heterogeneity of endothelial cells in culture. The formation of vascular networks was compared between fetal freshly isolated heart, liver, lung, and kidney endothelial cells embedded in collagen microfluidic channels [106]. After five days of gravity-driven flow, heart and lung cells form focal contacts, whereas kidney and liver cells form abundant fenestrations, being the liver ones discontinuous and irregular. Nevertheless, the extended signature lifespan from fetal endothelial cells might not be representative for adult organs [133,134].

Though heterogeneous reactions to shear stress have to some extent been studied, it is quite likely that stretch also plays a role, although it is studied to a much lesser degree. During inhalation, the alveolar-capillary barrier in alveoli stretches, and the ECM is compressed. Thus, besides shear stress and tissue stiffness, and as recently reviewed by Novak et al., pulmonary endothelial cells are markedly modulated by cyclic stretch during breath [164]. For instance, high amplitude cyclic stretch strain levels (i.e., 18 \% elongation) impair pulmonary artery endothelial cell barrier function, while barrier integrity is protected at physiological levels (approx. 5\%), with myosin light chain phosphorylation-thus, cytoskeleton rearrangement-being involved [121].

Importantly, cyclic stretch may also have a role in inflammation. High strains, such as $20 \%$, have been shown to activate the production of pro-inflammatory cytokines in pulmonary endothelial cells, including IL-8, IL-6 and MCP-1 [165]. Additionally, calcium $\left(\mathrm{Ca}^{2+}\right)$ influx in pulmonary endothelial cells is conditioned by cyclic stretch, being these channels activated at 20 to $30 \%$ cyclic stretch strains, but not at $10 \%$, and mediated by actin polymerization [123]. Cyclic stretch and shear stress transduced by mitochondria has been recently suggested as a novel mechanotransducer having a role in $\mathrm{Ca}^{2+}$ influx in lung endothelial cells. Yamamoto et al. observed how shear stresses between 1 and 8 dynes $/ \mathrm{cm}^{2}$ activated the mitochondrial production of adenosine triphosphate (ATP) and the $\mathrm{Ca}^{2+}$ influx mediated by Caveolin-1 [122].

\subsection{Biochemical Cues Determining Endothelial Cell Heterogeneity}

Most studies use generic protein coatings for their endothelial cell cultures, such as gelatin, fibronectin, or collagens, as shown in Table 1. However, the composition of the basement membrane and of the ECM in general, differs between organs and tissues, which may impact endothelial cell specialization, especially in the microvasculature [166]. Merna et al. described that lung and cardiac decellularized ECMs share several Collagens (I, III, IV, V, VI), Elastin, Fibrillin-1, Fibronectin 1 and Laminin, while Collagen II and IX were only present in lung, and Collagen VII, Fibrinogen and heparan sulfate proteoglycans were specific for cardiac ECMs [167]. Endothelial cells adhere to the basement membrane components through a repertoire of integrins. These are heterodimeric transmembrane receptors (composed of $\alpha$ and $\beta$ subunits) that, moreover, are responsible for shear-induced mechanotransduction signaling through the reorganization of the cytoskeleton, among others [168]. Therefore, organ-specific ECM compositions are closely linked to endothelial cell phenotypes.

In fact, using Fibronectin or Collagen alters the mechanosensitivity of endothelial cells [169] and of vascular smooth muscle cells [170]. Specifically, (bovine) aortic endothelial cells cultured on collagen and under shear stress showed only a transient ( $<30 \mathrm{~min}$ ) activation of the small GTPase RhoA, responsible for cell stiffening-associated with pathological 
conditions; this was inhibited by the shear-induced PECAM1/integrin-dependent activation of PKA. The authors suggest that the abundant collagen found in the descending aorta may be atheroprotective. On Fibronectin, instead, shear stress did not activate PKA, and endothelial cells had a prolonged RhoA activation [169]. Thus, acknowledging the specific basement membrane components and taking them into account in cell cultures, together with mechanical cues, is key to reaching more physiologically relevant experiments.

Bottom-up (or "discovery") proteomics by liquid chromatography and tandem mass spectrometry on decellularized tissues and in vitro produced ECMs, are providing new insights in the characterization of the basement membranes and ECMs from different organs [171]. Different components of ECMs associated with specific organs have been reported so far [167,172], and a Matrisome database (MatrisomeDB), launched by Naba and Gao [173,174], can be accessed online [175]. Yet, the database is only recent and mostly contains proteomic data of bulk ECMs from some organs, including the human liver and colon, as well as some diseased tissues. Only a few basement membrane characterizations, such as for human retinal vascular and human glomerular basement membranes, are included; even if some large veins and arteries have been characterized so far, basement membrane data on organ-specific microvasculatures is not yet available.

Interestingly, the aim of obtaining more physiologically relevant specific ECMs has led some groups to develop organ-specific ECM bio-inks from decellularized (porcine) tissues [176]. A less specialized commercial coating option offered by Corning is Matrigel, a mix of different ECM proteins produced by Engelbreth-Holm-Swarm mouse sarcoma tumor cells (including Laminin, Collagen IV, heparan sulfate proteoglycans, Entactin/Nidogen, and several growth factors). However, a common limitation for both decellularized ECM bio-inks and Matrigel is that they are batch-to-batch dependent, and thus they have an inherent variability associated that has not yet been traced.

\section{Organ-Specific Responses to Specific Biochemical Cues}

In the absence of the complete composition data for basement membranes from organspecific microvascular endothelial cells, the current best options to mimic their ECMs are: (i) the use of co-cultures (either in 2D or in 3D) with cells that would produce the ECM in situ, or (ii) the use of organ- or cell-derived ECMs (produced by the specific cell types of interest), regardless of their batch-to-batch limitation. Extracting the basement membrane from tissues may be cumbersome given the thin nature of this layer and the insolubility of many of its (mostly cross-linked) components [177]. Instead, Zhang et al. extracted the ECMs from skin, liver, and skeletal muscle decellularized tissues, and used them on (static) cultures with their respective endothelial cell types. They observed that when cells matched their ECM compositions, these showed a greater proliferation and differentiation capability [178]. Similarly, Bacci et al. produced and applied in vitro lung and cardiac ECMs to organ-specific endothelial cells, subjecting them to shear stress. Importantly, cardiac endothelial cells did not align under Fibronectin-coated surfaces [124,125] and aligned more on cardiac- and on lung-derived ECMs [125]. These studies demonstrate that when endothelial cells are cultured on generic coatings, part of their potential will be missing in vitro.

Romero Liguoni et al. also produced three hydrogels from decellularized (porcine) left ventricle, mitral valve, and aorta ECMs [132]. They characterized them biomechanically and tested them for vascular matrix formation with pulmonary microvascular endothelial cells co-cultured with adipose stromal cells. Collagen VI was the most abundant protein in the left ventricle and mitral valve matrices, while Elastin was the most abundant in aorta ECM. All three supported vascularization, but the ventricle ECM showed the greatest structures. Of note, aortic ECM was the stiffest one (around $7 \mathrm{kPa}$ ) and supported adipose cell myogenic differentiation, whereas valve and ventricle ECMs were both $3 \mathrm{kPa}$ and inhibited an induced (TGF- $\beta 1$ ) myogenic differentiation [132].

Decellularized kidney and liver ECMs have also been successfully used to maintain in vitro the viability and proliferation of human glomerular endothelial cells [179] and 
vascularized liver organoids [138], respectively. In the liver case, however, whole livers were decellularized and used as scaffolds. With regard to the brain, ECMs have been extracted and their compositions have been compared with the native tissue and Matrigel [180] or between different brain regions [181] using mass spectrometry; however, no endothelial studies have been performed with those yet. Recently, the use of organ-specific decellularized ECM hydrogels [182] and decellularized ECM scaffolds [183] have been reviewed elsewhere.

Endothelial cells are also exposed to tissue-specific soluble components in their native microenvironments. As commented in the previous section, the addition of arachidonic acid in the media was required for cardiac endothelial cells to align with the flow at 4 dynes $/ \mathrm{cm}^{2}$ [124]. Moreover, its inhibition in pulmonary endothelial cultures reduced their alignment to flow and their cell stiffness [124]. In another study, under the same conditions, heart endothelial cells had the greatest angiogenic capability after VEGF supplementation (also greatest oxygen consumption and glycolysis rates) compared to kidney, lung, and liver endothelial cells [106].

Although these have usually received little attention, paracrine signaling factors and pathways also have an organ-specific important impact on endothelial cells. Noteworthy, as recently exposed by Ricard et al., genetic variations in some signaling factors may lead to vascular diseases affecting specific organs instead of the vasculature in all organs [143]. That is, hereditary hemorrhagic telangiectasia (or HHT) caused by mutations in ACVRL1 and $E N G$, involves arteriovenous malformations mainly affecting the lungs and liver; or, mutations in BMPR2 may lead to pulmonary hypertension with no impairment of the endothelium in other organs [143].

Oxygen, or its absence during hypoxia, is known to regulate endothelial cell homeostasis. Hypoxia-inducible factor (HIF)- $\alpha$ subunits are hydroxylated and degraded under normal oxygen tension conditions. During hypoxia, apoptosis, oxidative stress, and angiogenesis are increased in an oxygen-dose and time-dependent manner: during short and mild exposures, anti-apoptotic pathways (i.e., NFKB signaling and HIF1 $\alpha$ and $\gamma \mathrm{H} 2 \mathrm{AX}$ DNA repair pathways) are activated. Instead, severe or longer exposures to mild hypoxia can lead to an increase in HIF1 $\alpha$ and promote apoptotic pathways [184]. The rise of HIF transcription factors in HUVECs after hypoxia has been suggested to increase vascular permeability, triggering inflammatory effects driven by the CD34-mediated differentiation of endothelial cells [185]. In the brain, chronic mild hypoxia disrupts the permeability in the BBB. Brain regions with greater hypoxia-induced vascular leakages also show the greatest angiogenic remodeling [186]. Thus, the increase in permeability is likely linked to a compensatory vascular remodeling (proliferation and angiogenesis), consistent with the switch of the normally expressed integrin $\alpha 6 \beta 1$ by $\alpha 5 \beta 1$ after cerebral hypoxia [187].

The adaptation of the endothelial cells to different levels of hypoxia occurs through a two-step mechanism involving initiation of angiogenesis (lead by HIF-1) and maturation of the vascular network (lead by HIF-2) [188]. Bartoszewski et al. reported that this HIF-1 to HIF-2 transition during hypoxia is conserved among nine bed-specific endothelial cell types (i.e., microvascular cardiac, dermal, lung, and uterine; aortic, cardiac artery and iliac; pulmonary artery endothelial cells, and HUVECs) [127]. However, HIF $\alpha$ subunits do have bed-specific behaviors under hypoxia modulating the ECM deposition by endothelial cells. Collagen type IV and Fibronectin are secreted by human umbilical artery endothelial cells (HUAECs) and HUVEC under both physiological $\left(5 \% \mathrm{O}_{2}\right)$ and hypoxic $\left(1 \% \mathrm{O}_{2}\right)$ conditions, whereas collagen type $\mathrm{I}$ is only deposited under physiological $\mathrm{O}_{2}$ levels [140]. Remarkably, the production of Collagen type IV and Fibronectin by HUAECs is mediated by HIF $1 \alpha$, whereas HIF $2 \alpha$ drives this process in HUVECs, suggesting tissue-specific mechanisms in different endothelial cell types. In addition, more immature cells (endothelial colonyforming cells) secrete collagen type I under physiological $\mathrm{O}_{2}$ conditions, but not Fibronectin and Collagen IV, which are deposited under saturated levels of $\mathrm{O}_{2}$ (or normoxia) [140]. 


\section{Impact of Endothelial Cell Heterogeneity on Drug Development}

Given the high diversity of phenotypes within the endothelial cell population and given their differential behavior in response to extrinsic factors, it is not surprising that the use of generic targets in vascular repair, revascularization, or in cancer treatments (such as VEGFR) entail low efficiencies and suffer from side effects $[189,190]$. New molecular and genetic knowledge in endothelial heterogeneity implies that endothelial cells from different origins may not respond equally to drugs. In fact, organ-specific endothelial cells show differential reactivity to inflammatory stimuli, such as cytokines, and this entails pharmacological implications [144]. In this regard, more research is being focused on the characterization of the heterogeneous inflammatory response of endothelial cells for the development of anti-inflammatory therapies against chronic inflammatory diseases [191].

In recent decades, the unique properties of some endothelia have been studied and exploited in the development of therapeutics. In cancer, the heterogeneity of tumor endothelial cells has proven to present interesting opportunities for drug delivery, as has been reviewed elsewhere [192]. Interestingly, the unique properties of the tumor vasculature have been demonstrated to carry a better potential for tumor targeting than the tumor cells themselves, and novel anti-tumor strategies are emerging [193,194]. Another endothelium that has raised a great interest in drug development is that in the BBB. The tight nature of this vasculature becomes a challenge in terms of drug delivery and, thus, in vitro BBB models are being developed to test brain-targeting drugs $[195,196]$. Despite their debatable resemblance with their primary counterparts, patient-specific endothelial cells derived from pluripotent stem cells have emerged as a promising tool with the added value of their potential for more personalized drug development [197]. While the heterogeneity of endothelial cells represents a challenge for designing tailored revascularization strategies, it also generates opportunities for vascular bed-specific and more efficient delivery of drugs, as recently reviewed [198].

Still, the knowledge on endothelial heterogeneity across different organs, tissues, and species is constantly increasing, and a giant leap towards its full integration and consideration in the design of new drug delivery strategies, as well as in tissue engineering and regenerative medicine, must be taken to reduce off-target effects. 
Table 1. Organs targeted for the characterization of endothelial cells using in vitro culture techniques, including the strategies used for the maintenance of organ-specific endothelial cell signatures.

\begin{tabular}{|c|c|c|c|c|c|c|c|c|c|c|}
\hline \multirow{2}{*}{$\begin{array}{l}\text { Organ/ } \\
\text { Tissue }\end{array}$} & \multirow{2}{*}{ Cell Type } & \multirow{2}{*}{ Pass. Nr. } & \multirow{2}{*}{ Co-Culture } & \multicolumn{2}{|c|}{ Tissue Mimicking } & \multicolumn{3}{|c|}{ Characterization Technique } & \multirow{2}{*}{$\begin{array}{l}\text { Time in } \\
\text { Culture }\end{array}$} & \multirow{2}{*}{ Refs } \\
\hline & & & & Mechanical & Biochemical & Genetics & Morphology & Function & & \\
\hline \multirow{8}{*}{ Brain } & \multirow{2}{*}{$\begin{array}{c}\text { human brain } \\
\text { microvascular (mv) } \\
\text { ECs (HBMECs) (C) }\end{array}$} & P2-P3 & $\begin{array}{l}\text { human } \\
\text { astrocytes }\end{array}$ & $\begin{array}{c}6.2 \text { dynes } / \mathrm{cm}^{2} ; \\
\text { PP } \\
\text { hollow fibers }\end{array}$ & FN & $\begin{array}{c}\text { RNA } \\
\text { microarray }\end{array}$ & - & $\begin{array}{l}\text { TEER; glucose } \\
\text { consumption } \\
\text { and lactate } \\
\text { production }\end{array}$ & $30 \mathrm{~d}$ & [118] \\
\hline & & P4-P7 & - & $\begin{array}{l}10-20, \\
40 \text { dynes } / \mathrm{cm}^{2} ; \\
\text { silicone }\end{array}$ & $\begin{array}{c}\mathrm{FN}+ \\
\text { Astrocyte } \\
\text { conditioned } \\
\text { medium }\end{array}$ & - & $\begin{array}{l}\text { IF: CD31, ZO-1 and } \\
\text { CLDN-5; WB: } \\
\text { Transport markers } \\
\text { P-gp and GLUT1 }\end{array}$ & $\begin{array}{l}\text { Src/ERK } \\
\text { pathway } \\
\text { activation }\end{array}$ & $4 \mathrm{~d}$ & [161] \\
\hline & $\begin{array}{l}\text { bovine primary } \\
\text { BMECs (F) }\end{array}$ & P1-P7 & $\begin{array}{l}\text { Glial cells } \\
\text { (astrocytes } \\
>95 \%)(\mathrm{F})\end{array}$ & - & Col solution & - & $\begin{array}{l}\text { IF: CLDN, OCLN, } \\
\mathrm{ZO}, \beta \text {-cat, p120 } \\
\text { actin cytoskeleton }\end{array}$ & $\begin{array}{l}\text { Permeability } \\
\text { assays }\end{array}$ & $14 \mathrm{~d}$ & [129] \\
\hline & $\begin{array}{l}\text { mouse primary } \\
\text { BMECs }(F)\end{array}$ & P1 & - & - & Matrigel & $\begin{array}{c}\text { RNA-seq, } \\
\text { transcriptome }\end{array}$ & $\begin{array}{c}\text { IF: CLDN-5, OCLN, } \\
\text { ZO-1, ZO-2, JAM-A, } \\
\text { VE-cad \& } \beta \text {-cat }\end{array}$ & TEER & $7 \mathrm{~d}$ & [130] \\
\hline & $\begin{array}{l}\text { mouse primary } \\
\text { BECs }(\mathrm{F})\end{array}$ & P1 & - & - & Col I & $\begin{array}{l}\text { RNA-seq and } \\
\text { ATAC-seq }\end{array}$ & IF: CD31 & - & $10 \mathrm{~d}$ & [131] \\
\hline & $\begin{array}{l}\text { iPSCs-derived } \\
\text { HBMECs \& human } \\
\text { umbilical vein ECs } \\
\text { (HUVECs) (D) }\end{array}$ & P1-P7 & - & $\begin{array}{c}\sim 4 \text { dynes } / \mathrm{cm}^{2} \\
\text { cylindrical } \\
150 \mu \mathrm{m} \varnothing \\
\text { channel Col } \\
\text { hydrogel }\end{array}$ & Col I & $\begin{array}{l}\text { GLUT1 and } \\
\text { P-gp } \\
\text { expression }\end{array}$ & $\begin{array}{l}\text { IF: ZO-1, CLDN-5 } \\
\text { and OCLN }\end{array}$ & $\begin{array}{l}\text { Permeability } \\
\text { assays }\end{array}$ & $6 \mathrm{~d}$ & [133] \\
\hline & $\begin{array}{l}\text { iPSCs-derived } \\
\text { HBMECs (D) }\end{array}$ & P2 & - & - & $\begin{array}{l}\text { Genipin- } \\
\text { crosslinked } \\
\text { Col I gels, } \\
\text { with FN and } \\
\text { Col IV }\end{array}$ & - & $\begin{array}{l}\text { IF: ZO-1 and } \\
\text { CLDN-5 }\end{array}$ & $\begin{array}{c}\text { TEER, } \\
\text { microvessel } \\
\text { formation }\end{array}$ & $7 \mathrm{~d}$ & [135] \\
\hline & $\begin{array}{l}\text { hESCs-derived } \\
\text { ECs (D) }\end{array}$ & - & $\begin{array}{l}\text { hESCs- } \\
\text { derived } \\
\text { cortical } \\
\text { organoids }\end{array}$ & Perfusion tests & $\begin{array}{c}\text { cortical } \\
\text { organoids }\end{array}$ & $\begin{array}{l}\text { TJ \& nutrient } \\
\text { transporter } \\
\text { expression; } \\
\text { single-cell } \\
\text { map vhCOs }\end{array}$ & - & TEER & $120 \mathrm{~d}$ & [134] \\
\hline
\end{tabular}


Table 1. Cont.

\begin{tabular}{|c|c|c|c|c|c|c|c|c|c|c|}
\hline \multirow{2}{*}{$\begin{array}{l}\text { Organ/ } \\
\text { Tissue }\end{array}$} & \multirow{2}{*}{ Cell Type } & \multirow{2}{*}{ Pass. Nr. } & \multirow{2}{*}{ Co-Culture } & \multicolumn{2}{|c|}{ Tissue Mimicking } & \multicolumn{3}{|c|}{ Characterization Technique } & \multirow{2}{*}{$\begin{array}{l}\text { Time in } \\
\text { Culture }\end{array}$} & \multirow{2}{*}{ Refs } \\
\hline & & & & Mechanical & Biochemical & Genetics & Morphology & Function & & \\
\hline & $\begin{array}{l}\text { Immortalized } \\
\text { mouse BMECs } \\
\text { (bEnd3) (C) }\end{array}$ & - & $\begin{array}{c}\text { patient- } \\
\text { derived } \\
\text { glioblastoma } \\
\text { cells }\end{array}$ & Alginate fibers & $\begin{array}{l}\text { thiolated } \\
\text { sodium } \\
\text { hyaluronate }\end{array}$ & qPCR & IF & VEGF release & $14 \mathrm{~d}$ & [119] \\
\hline & $\begin{array}{l}\text { Immortalized } \\
\text { HBMECs; } \\
\text { HUVECs }(C)\end{array}$ & - & - & $\begin{array}{c}8,12, \\
16 \text { dynes } / \mathrm{cm}^{2}\end{array}$ & - & - & $\begin{array}{l}\text { IF: F-actin and ZO- } 1 \text {; } \\
\text { WB: } \beta \text {-catenin and } \\
\text { ZO- } 1 \text {; cell alignment }\end{array}$ & - & $36 \mathrm{~h}$ & [120] \\
\hline \multirow{5}{*}{ Lung } & \multirow{2}{*}{$\begin{array}{c}\text { human pulmonary } \\
\text { artery ECs } \\
\text { (HPAECs) (C) }\end{array}$} & P6-P8 & - & $\begin{array}{c}\text { flexible- } \\
\text { bottomed } \\
\text { BioFlex plates; } \\
5 \text { and } 18 \% \\
\text { elongation } \\
\text { cyclic stretch }\end{array}$ & Col I & gene profiling & $\begin{array}{l}\text { IF: F-actin; stress } \\
\text { fiber \& actin } \\
\text { alignment; WB: } \\
\text { pathway factors }\end{array}$ & $\begin{array}{l}\text { cytoskeletal } \\
\text { rearrang. } \\
\text { \& TEER }\end{array}$ & $2 \mathrm{~d}$ & [121] \\
\hline & & P7-P10 & - & $\begin{array}{c}1,3, \\
8 \text { dynes } / \mathrm{cm}^{2} \\
\text { glass }\end{array}$ & Gelatin & - & $\begin{array}{l}\text { IF: MitoTracker and } \\
\text { caveolin-1 }\end{array}$ & $\begin{array}{l}\text { Real-time } \\
\text { imaging: mit. } \\
\text { ATP levels; } \\
\mathrm{Ca}^{2+} \text { influx }\end{array}$ & few min & [122] \\
\hline & $\begin{array}{c}\text { human pulmonary } \\
\text { mv ECs } \\
\text { (HPMECs) (C) }\end{array}$ & P4-P7 & - & $\begin{array}{c}\text { silicon } \\
\text { chamber; } 10, \\
20,30 \% \\
\text { stretch strains }\end{array}$ & FN & $\begin{array}{c}\text { qPCR: TRPV-2, } \\
\text { TRPV-4 }\end{array}$ & $\begin{array}{c}\text { IF: Tie-2, CD31, } \\
\text { F-actin }\end{array}$ & $\begin{array}{c}\text { Stretch- } \\
\text { activated } \\
\mathrm{Ca}^{2+} \text { influx }\end{array}$ & few min & [123] \\
\hline & \multirow{2}{*}{$\begin{array}{l}\text { mouse primary } \\
\text { PMECs \& cardiac } \\
\text { mv ECs (both } \\
\text { E4ORF1) (C) }\end{array}$} & - & - & $\begin{array}{l}4 \text { dynes } / \mathrm{cm}^{2} \\
\text { PS slides }\end{array}$ & FN & - & $\begin{array}{l}\text { FC: CD31, CD144; } \\
\text { cell alignment \& } \\
\text { area; AFM: cell stiff. }\end{array}$ & - & $12 \mathrm{~h}$ & [124] \\
\hline & & - & - & $\begin{array}{c}2 \text { dynes } / \mathrm{cm}^{2} \\
\text { PDMS } \\
(500 \mathrm{kPa}) \text { and } \\
\text { PS (2-3 GPa) } \\
\text { slides }\end{array}$ & $\begin{array}{c}\text { Cardiac \& } \\
\text { lung ECM vs. } \\
\text { FN }\end{array}$ & - & $\begin{array}{c}\text { cell alignment and } \\
\text { area; FC: integrins } \\
\quad \alpha \mathrm{v} \text { and } \beta 3\end{array}$ & - & $12 \mathrm{~h}$ & [125] \\
\hline
\end{tabular}


Table 1. Cont.

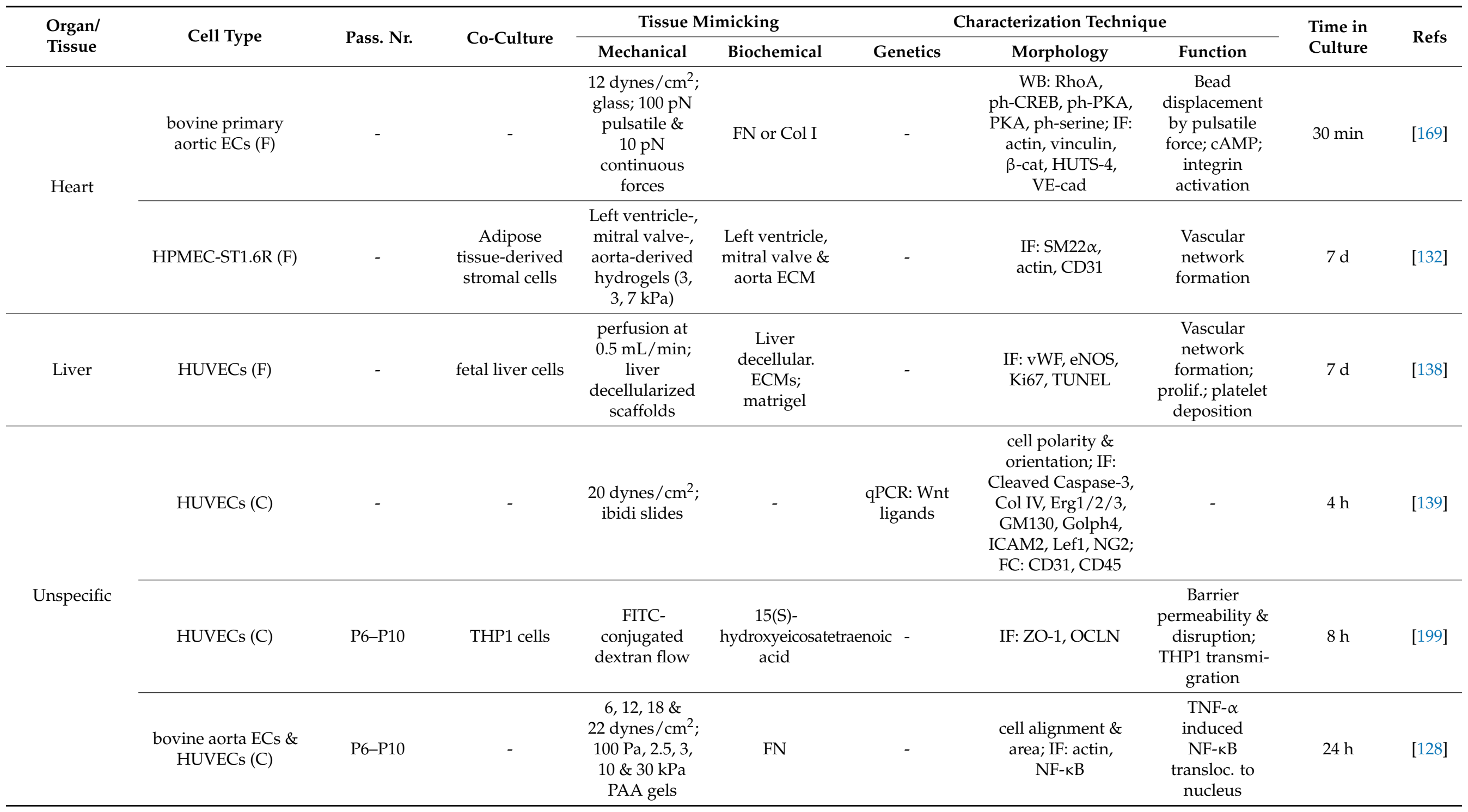


Table 1. Cont.

\begin{tabular}{|c|c|c|c|c|c|c|c|c|c|c|}
\hline \multirow{2}{*}{$\begin{array}{l}\text { Organ/ } \\
\text { Tissue }\end{array}$} & \multirow{2}{*}{ Cell Type } & \multirow{2}{*}{ Pass. Nr. } & \multirow{2}{*}{ Co-Culture } & \multicolumn{2}{|c|}{ Tissue Mimicking } & \multicolumn{3}{|c|}{ Characterization Technique } & \multirow{2}{*}{$\begin{array}{l}\text { Time in } \\
\text { Culture }\end{array}$} & \multirow{2}{*}{ Refs } \\
\hline & & & & Mechanical & Biochemical & Genetics & Morphology & Function & & \\
\hline & $\begin{array}{c}\text { human pulmonary } \\
\text { artery ECs } \\
\text { (HPAECs) (C) }\end{array}$ & P5-P9 & - & $\begin{array}{c}1.1 \& 40 \mathrm{kPa} \\
\text { hydrogels, or } \\
\text { glass } \\
(\sim 50 \mathrm{GPa})\end{array}$ & FN or Col IV & - & $\begin{array}{l}\text { IF: VE-cad, } \\
\text { paxillin, actin }\end{array}$ & $\begin{array}{l}\text { Magnetic } \\
\text { twisting } \\
\text { cytometry for } \\
\text { VE-cad } \\
\text { receptor } \\
\text { perturbation \& } \\
\text { displacement; } \\
\text { Monolayer } \\
\text { stress } \\
\text { microscopy }\end{array}$ & $5 \mathrm{~d}$ & [200] \\
\hline & $\begin{array}{l}\text { immortalized } \\
\text { human mv ECs } \\
\text { (HMEC-1) \& } \\
\text { HUVECs (C) }\end{array}$ & P4-P8 & - & $\begin{array}{c}3,35 \& 70 \mathrm{kPa} \\
\text { PAA gels }\end{array}$ & Col I & $\begin{array}{l}\text { Transcriptom. } \\
\text { and qPCR }\end{array}$ & $\begin{array}{c}\text { IF: pMLC \& actin } \\
\text { \& WB }\end{array}$ & $\begin{array}{l}\text { Traction force } \\
\text { microscopy }\end{array}$ & $2 \mathrm{~h}$ & [156] \\
\hline & $\begin{array}{l}\text { human umbilical } \\
\text { artery ECs } \\
\text { (HUAECs) \& } \\
\text { HUVECs (C) }\end{array}$ & - & - & - & Col I; hypoxia & $\begin{array}{c}\text { qPCR: } \beta \text {-actin, } \\
\text { HPRT1 }\end{array}$ & $\begin{array}{l}\text { FC: VE-cad, CD31, } \\
\text { KDR, CD146, } \\
\text { PDGFR } \beta \text {; IF \& WB: } \\
\text { Col I, Col IV, FN, } \\
\text { laminin, actin }\end{array}$ & $\begin{array}{c}\text { Hypoxia \& } \\
\text { conditioned } \\
\text { ECM } \\
\text { deposition }\end{array}$ & $7 \mathrm{~d}$ & [140] \\
\hline \multirow[b]{2}{*}{ Diverse } & $\begin{array}{c}\text { fetal human } \\
\text { primary kidney, } \\
\text { lung, liver \& heart } \\
\text { ECs (F) }\end{array}$ & P2-P5 & $\begin{array}{l}\text { rat primary } \\
\text { hepatocytes }\end{array}$ & $\begin{array}{l}\text { Gravity- } \\
\text { driven flow; } \\
\text { cells in Col } \\
\text { microfluidic } \\
\text { channels }\end{array}$ & Col I & $\begin{array}{l}\text { RNAseq of } \\
\text { freshly } \\
\text { isolated vs. } \\
\text { cultured ECs }\end{array}$ & $\begin{array}{c}\text { IF: CD31, CD144, } \\
\text { vWF, PV1 \& } \\
\text { Caveolin } 1\end{array}$ & $\begin{array}{l}\text { TEER, } \\
\text { spheroid } \\
\text { sprouting, } \\
\text { metabolic } \\
\text { assays }\end{array}$ & $5 \mathrm{~d}$ & [106] \\
\hline & $\begin{array}{c}\text { human primary mv } \\
\text { dermal, lung, renal } \\
\text { glomerular, brain \& } \\
\text { liver ECs; large } \\
\text { vessel coronary } \\
\text { artery ECs \& } \\
\text { HUVECs (C) }\end{array}$ & P2-P8 & - & - & $\begin{array}{c}\text { Dilutions of } \\
\text { TTP/sporadic } \\
\text { HUS patients' } \\
\text { plasma }\end{array}$ & $\begin{array}{l}\text { qPCR: Fas } \\
\text { transcripts }\end{array}$ & FC: annexin II & $\begin{array}{l}\text { Apoptosis: } \\
\text { Cdc2 kinase } \\
\text { assay, } \\
\text { procoagulant } \\
\text { activities }\end{array}$ & $16-18 \mathrm{~h}$ & [126] \\
\hline
\end{tabular}


Table 1. Cont.

\begin{tabular}{|c|c|c|c|c|c|c|c|c|c|c|}
\hline \multirow{2}{*}{$\begin{array}{l}\text { Organ/ } \\
\text { Tissue }\end{array}$} & \multirow{2}{*}{ Cell Type } & \multirow{2}{*}{ Pass. Nr. } & \multirow{2}{*}{ Co-Culture } & \multicolumn{2}{|c|}{ Tissue Mimicking } & \multicolumn{3}{|c|}{ Characterization Technique } & \multirow{2}{*}{$\begin{array}{l}\text { Time in } \\
\text { Culture }\end{array}$} & \multirow{2}{*}{ Refs } \\
\hline & & & & Mechanical & Biochemical & Genetics & Morphology & Function & & \\
\hline & $\begin{array}{l}\text { human primary mv } \\
\text { cardiac, dermal, } \\
\text { lung \& uterine ECs; } \\
\text { aortic, cardiac artery, } \\
\text { iliac ECs, HPAECs } \\
\text { \& HUVECs (C) }\end{array}$ & P2-P6 & - & - & Hypoxia & $\begin{array}{c}\text { Gene } \\
\text { expression } \\
\text { microarray; } \\
\text { qPCR: HIF1A, } \\
\text { HIF-2a, 18S, } \\
\text { TBP }\end{array}$ & $\begin{array}{c}\text { WB: HIF-1a, HIF-2a; } \\
\beta \text {-actin }\end{array}$ & $\begin{array}{l}\text { Hypoxia } \\
\text { effects in } \\
\text { transcriptome }\end{array}$ & $2 \mathrm{~d}$ & [127] \\
\hline & $\begin{array}{c}\text { human } \\
\text { adipose-derived } \\
\text { endothelial cells \& } \\
\text { HUVECs (F); } \\
\text { human mv cardiac, } \\
\text { aortic, pulmonary } \\
\text { and dermal ECs (C); } \\
\text { ETV2-transduced. }\end{array}$ & P5-P10 & $\begin{array}{c}\text { Colorect. } \\
\text { cancer, colon \& } \\
\text { small intestine } \\
\text { organoids; } \\
\text { pancreat. islets }\end{array}$ & $\begin{array}{l}\text { Gravity- } \\
\text { driven } \\
\text { perfusion tests } \\
\text { in microfluidic } \\
\text { devices }\end{array}$ & $\begin{array}{l}\text { Matrigel or } \\
\text { mixture of } \\
\text { laminin, } \\
\text { entactin \& col } \\
\text { IV }\end{array}$ & $\begin{array}{l}\text { single-cell } \\
\text { transcriptom. } \\
\text { \& epigenetics }\end{array}$ & $\begin{array}{l}\text { IF: VE-cad, CD31, } \\
\text { PDGFR } \beta \text {; FC: CD31, } \\
\text { CD45; WB: RAP1, } \\
\text { ETV2, ETS1, p-AKT; } \\
\text { vessel area }\end{array}$ & $\begin{array}{l}\text { Vascular tube } \\
\text { formation; } \\
\text { glucose- } \\
\text { responsive } \\
\text { insulin- } \\
\text { secreting } \\
\text { (islets); } \\
\text { intestine \& } \\
\text { organoid vas- } \\
\text { cularization }\end{array}$ & $12 \mathrm{w}$ & [136] \\
\hline
\end{tabular}

Pass., passage; C, commercial; D, derived; F, freshly isolated; ECM, extracellular matrix; Col, collagen; FN, fibronectin; FC, flow cytometry; IF, immunofluorescence; WB, western blot PAA, polyacrylamide; PDMS, polydimethylsiloxane; PP, polypropylene; PS, polystyrene; ph, phospho-; AFM, atomic force microscopy; TEER, transendothelial electrical resistance; TJ, tight junction; $\beta$-cat, $\beta$-catenin; CLDN, claudin; CREB, cAMP-response element binding protein; ETV2, ETS variant transcription factor 2; HIF, hypoxia-inducible factors; ICAM, Intercellular Adhesion Molecule; JAM, junctional adhesion molecules; KDR, Kinase insert domain receptor; NG2, Neuron-glial antigen 2; OCLN, occludin; PDGFR $\beta$, Platelet-derived growth factor receptor $\beta$; PV1, plasmalemma vesicle-associated protein; RAP1, Ras-Association Proximate 1; SM22 $\alpha$, Smooth muscle protein $22 \alpha$; VE-cad, VE-cadherin; vWF, Von Willebrand factor; ZO, zona occludens; $\mathrm{d}$, days; $\mathrm{h}$, hours; $\mathrm{w}$, weeks; (-), not mentioned data. 


\section{Conclusions}

In recent decades, both mechanical and biochemical cues have been demonstrated to have a huge impact on the behavior of organ-specific endothelial cells. Nevertheless, in most in vitro research, these cells are being cultured on plastic or glass surfaces, under static conditions, and/or on generic protein (mostly single) coatings to promote cell attachment. Furthermore, difficulties in keeping tissue-specific characteristics have led to the use of insufficiently specialized endothelial cell types in most research papers. New transcriptomic and proteomic insights are being revealed for the characterization of these bed-specific endothelial cells. Furthermore, new approaches are being developed to mimic the endothelial cell microenvironment, such as hydrogels and microfluidic strategies. In addition, biophysicists and molecular biologists are joining forces to improve the current understanding of organ-specific vascular mechanobiology. Therefore, it is crucial to put all this knowledge and technological potential together to facilitate the transition from the generic characterization of the endothelial cell behavior to more specialized readouts.

Author Contributions: L.G.-R., M.D., A.L. and E.A.V.J. contributed to writing, editing, and creating figures. All authors contributed to the article and approved the submitted version. All authors have read and agreed to the published version of the manuscript.

Funding: This work was supported by the Fonds voor Wetenschappelijk Onderzoek (G091018N, G0B5920N, G099521N) and by internal funding from the KU Leuven (IDN/19/031). L.G.-R. received funding from the European Union's Horizon 2020 research and innovation programme under the Marie Sklodowska-Curie grant agreement No 101025264. M.D. received funding from the Fonds voor Wetenschappelijk Onderzoek (1107721N).

Institutional Review Board Statement: Not applicable.

Conflicts of Interest: The authors declare no conflict of interest.

\section{References}

1. Cleaver, O.; Melton, D.A. Endothelial signaling during development. Nat. Med. 2003, 9, 661-668. [CrossRef] [PubMed]

2. Jourde-Chiche, N.; Fakhouri, F.; Dou, L.; Bellien, J.; Burtey, S.; Frimat, M.; Jarrot, P.A.; Kaplanski, G.; Le Quintrec, M.; Pernin, V.; et al. Endothelium structure and function in kidney health and disease. Nat. Rev. Nephrol. 2019, 15, 87-108. [CrossRef] [PubMed]

3. Miyata, S. New aspects in fenestrated capillary and tissue dynamics in the sensory circumventricular organs of adult brains. Front. Neurosci. 2015, 9, 390. [CrossRef] [PubMed]

4. Muller, W.A. Getting Leukocytes to the Site of Inflammation. Vet. Pathol. 2013, 50, 7. [CrossRef]

5. $\quad$ Parkar, N.S.; Akpa, B.S.; Nitsche, L.C.; Wedgewood, L.E.; Place, A.T.; Sverdlov, M.S.; Chaga, O.; Minshall, R.D. Vesicle Formation and Endocytosis: Function, Machinery, Mechanisms, and Modeling. Antioxid. Redox Signal. 2009, 11, 1301. [CrossRef]

6. Milici, A.J.; Furie, M.B.; Carley, W.W. The formation of fenestrations and channels by capillary endothelium in vitro. Proc. Natl. Acad. Sci. USA 1985, 82, 6181-6185. [CrossRef]

7. Rubin, L.L.; Hall, D.E.; Porter, S.; Barbu, K.; Cannon, C.; Horner, H.C.; Janatpour, M.; Liaw, C.W.; Manning, K.; Morales, J.; et al. A cell culture model of the blood-brain barrier. J. Cell Biol. 1991, 115, 1725-1735. [CrossRef]

8. Chi, J.T.; Chang, H.Y.; Haraldsen, G.; Jahnsen, F.L.; Troyanskaya, O.G.; Chang, D.S.; Wang, Z.; Rockson, S.G.; Van De Rijn, M.; Botstein, D.; et al. Endothelial cell diversity revealed by global expression profiling. Proc. Natl. Acad. Sci. USA 2003, 100, 10623-10628. [CrossRef]

9. Burridge, K.A.; Friedman, M.H. Environment and vascular bed origin influence differences in endothelial transcriptional profiles of coronary and iliac arteries. Am. J. Physiol. Hear. Circ. Physiol. 2010, 299, H837-H846. [CrossRef]

10. Coultas, L.; Chawengsaksophak, K.; Rossant, J. Endothelial cells and VEGF in vascular development. Nature 2005, 438, 937-945. [CrossRef]

11. Yamaguchi, T.P.; Dumont, D.J.; Conlon, R.A.; Breitman, M.L.; Rossant, J. Flk-1, an fit-related receptor tyrosine kinase is an early marker for endothelial cell precursors. Development 1993, 118, 489-498. [CrossRef]

12. Drake, C.J.; Fleming, P.A. Vasculogenesis in the day 6.5 to 9.5 mouse embryo. Blood 2000, 95, 1671-1679. [CrossRef]

13. Carmeliet, P.; Ferreira, V.; Breier, G.; Pollefeyt, S.; Kieckens, L.; Gertsenstein, M.; Fahrig, M.; Vandenhoeck, A.; Harpal, K.; Eberhardt, C.; et al. Abnormal blood vessel development and lethality in embryos lacking a single VEGF allele. Nature 1996, 380, 435-439. [CrossRef]

14. Ferrara, N.; Carver-Moore, K.; Chen, H.; Dowd, M.; Lu, L.; O'Shea, K.S.; Powell-Braxton, L.; Hillan, K.J.; Moore, M.W. Heterozygous embryonic lethality induced by targeted inactivation of the VEGF gene. Nature 1996, 380, 439-442. [CrossRef]

15. Shalaby, F.; Janet, R.; Yamaguchi, T.P.; Gertsenstein, M.; Wu, X.F.; Breitman, M.L.; Schuh, A.C. Failure of blood-island formation and vasculogenesis in Flk-1-deficient mice. Nature 1995, 376, 62-66. [CrossRef] 
16. Fong, G.H.; Rossant, J.; Gertsenstein, M.; Breitman, M.L. Role of the Flt-1 receptor tyrosine kinase in regulating the assembly of vascular endothelium. Nature 1995, 376, 66-70. [CrossRef]

17. De Val, S.; Anderson, J.P.; Heidt, A.B.; Khiem, D.; Xu, S.M.; Black, B.L. Mef2c is activated directly by Ets transcription factors through an evolutionarily conserved endothelial cell-specific enhancer. Dev. Biol. 2004, 275, 424-434. [CrossRef]

18. Ferdous, A.; Caprioli, A.; Iacovino, M.; Martin, C.M.; Morris, J.; Richardson, J.A.; Latif, S.; Hammer, R.E.; Harvey, R.P.; Olson, E.N.; et al. Nkx2-5 transactivates the Ets-related protein 71 gene and specifies an endothelial/endocardial fate in the developing embryo. Proc. Natl. Acad. Sci. USA 2009, 106, 814-819. [CrossRef]

19. Lee, D.; Park, C.; Lee, H.; Lugus, J.J.; Kim, S.H.; Arentson, E.; Chung, Y.S.; Gomez, G.; Kyba, M.; Lin, S.; et al. ER71 Acts Downstream of BMP, Notch, and Wnt Signaling in Blood and Vessel Progenitor Specification. Cell Stem Cell 2008, 2, $497-507$. [CrossRef]

20. Greenberg, J.M.; Thompson, F.Y.; Brooks, S.K.; Shannon, J.M.; McCormick-Shannon, K.; Cameron, J.E.; Mallory, B.P.; Akeson, A.L. Mesenchymal expression of vascular endothelial growth factors D and A defines vascular patterning in developing lung. Dev. Dyn. 2002, 224, 144-153. [CrossRef]

21. Yang, J.; Hernandez, B.J.; Alanis, D.M.; del Pilar, O.N.; Vila-Ellis, L.; Akiyama, H.; Evans, S.E.; Ostrin, E.J.; Chen, J. The development and plasticity of alveolar type 1 cells. Development 2016, 143, 54-65. [CrossRef] [PubMed]

22. Parera, M.C.; Van Dooren, M.; Van Kempen, M.; De Krijger, R.; Grosveld, F.; Tibboel, D.; Rottier, R. Distal angiogenesis: A new concept for lung vascular morphogenesis. Am. J. Physiol. Lung Cell. Mol. Physiol. 2005, 288, 141-149. [CrossRef] [PubMed]

23. Scott, C.L.; Walker, D.J.; Cwiklinski, E.; Tait, C.; Tee, A.R.; Land, S.C. Control of HIF-1 $\alpha$ and vascular signaling in fetal lung involves cross talk between mTORC1 and the FGF-10/FGFR2b/Spry2 airway branching periodicity clock. Am. J. Physiol. Lung Cell. Mol. Physiol. 2010, 299, 455-471. [CrossRef] [PubMed]

24. White, A.C.; Lavine, K.J.; Ornitz, D.M. FGF9 and SHH regulate mesenchymal Vegfa expression and development of the pulmonary capillary network. Development 2007, 134, 3743-3752. [CrossRef]

25. Giordano, F.J.; Gerber, H.P.; Williams, S.P.; Vanbruggen, N.; Bunting, S.; Ruiz-Lozano, P.; Gu, Y.; Nath, A.K.; Huang, Y.; Hickey, R.; et al. A cardiac myocyte vascular endothelial growth factor paracrine pathway is required to maintain cardiac function. Proc. Natl. Acad. Sci. USA 2001, 98, 5780-5785. [CrossRef]

26. Winnier, G.; Blessing, M.; Labosky, P.A.; Hogan, B.L.M. Bone morphogenetic protein-4 is required for mesoderm formation and patterning in the mouse. Genes Dev. 1995, 9, 2105-2116. [CrossRef]

27. Chang, H.; Huylebroeck, D.; Verschueren, K.; Guo, Q.; Matzuk, M.M.; Zwijsen, A. Smad5 knockout mice die at mid-gestation due to multiple embryonic and extraembryonic defects. Development 1999, 126, 1631-1642. [CrossRef]

28. Sirard, C.; De La Pompa, J.L.; Elia, A.; Itie, A.; Mirtsos, C.; Cheung, A.; Hahn, S.; Wakeham, A.; Schwartz, L.; Kern, S.E.; et al. The tumor suppressor gene Smad4/Dpc4 is required for gastrulation and later for anterior development of the mouse embryo. Genes Dev. 1998, 12, 107-119. [CrossRef]

29. Yang, X.; Li, C.; Xu, X.; Deng, C. The tumor suppressor SMAD4/DPC4 is essential for epiblast proliferation and mesoderm induction in mice. Proc. Natl. Acad. Sci. USA 1998, 95, 3667-3672. [CrossRef]

30. Kelly, M.A.; Hirschi, K.K. Signaling hierarchy regulating human endothelial cell development. Arterioscler. Thromb. Vasc. Biol. 2009, 29, 718-724. [CrossRef]

31. Daems, M.; Peacock, H.M.; Jones, E.A.V. Fluid flow as a driver of embryonic morphogenesis. Development 2020, 147, 1-40. [CrossRef]

32. Aird, W.C. Phenotypic heterogeneity of the endothelium: I. Structure, function, and mechanisms. Circ. Res. 2007, 100, 158-173. [CrossRef]

33. Lucitti, J.L.; Jones, E.A.V.; Huang, C.; Chen, J.; Fraser, S.E.; Dickinson, M.E. Vascular remodeling of the mouse yolk sac requires hemodynamic force. Development 2007, 134, 3317-3326. [CrossRef]

34. Chouinard-Pelletier, G.; Jahnsen, E.D.; Jones, E.A. V Increased shear stress inhibits angiogenesis in veins and not arteries during vascular development. Angiogenesis 2013, 16, 71-83. [CrossRef]

35. le Noble, F.; Moyon, D.; Pardanaud, L.; Yuan, L.; Djonov, V.; Matthijsen, R.; Bréant, C.; Fleury, V.; Eichmann, A. Flow regulates arterial-venous differentiation in the chick embryo yolk sac. Development 2004, 131, 361-375. [CrossRef]

36. Chong, D.C.; Koo, Y.; Xu, K.; Fu, S.; Cleaver, O. Stepwise arteriovenous fate acquisition during mammalian vasculogenesis. Dev. Dyn. 2011, 240, 2153-2165. [CrossRef]

37. Buschmann, I.; Pries, A.; Styp-Rekowska, B.; Hillmeister, P.; Loufrani, L.; Henrion, D.; Shi, Y.; Duelsner, A.; Hoefer, I.; Gatzke, N.; et al. Pulsatile shear and Gja5 modulate arterial identity and remodeling events during flow-driven arteriogenesis. Development 2010, 137, 2187-2196. [CrossRef]

38. Stenman, J.M.; Rajagopal, J.; Carroll, T.J.; Ishibashi, M.; McMahon, J.; McMahon, A.P. Canonical Wnt signaling regulates organ-specific assembly and differentiation of CNS vasculature. Science 2008, 322, 1247-1250. [CrossRef]

39. Daneman, R.; Agalliu, D.; Zhou, L.; Kuhnert, F.; Kuo, C.J.; Barres, B.A. Wnt/ $\beta$-catenin signaling is required for CNS, but not non-CNS, angiogenesis. Proc. Natl. Acad. Sci. USA 2009, 106, 641-646. [CrossRef]

40. Zhou, Y.; Wang, Y.; Tischfield, M.; Williams, J.; Smallwood, P.M.; Rattner, A.; Taketo, M.M.; Nathans, J. Canonical WNT signaling components in vascular development and barrier formation. J. Clin. Investig. 2014, 124, 3825-3846. [CrossRef] 
41. He, L.; Vanlandewijck, M.; Mäe, M.A.; Andrae, J.; Ando, K.; Del Gaudio, F.; Nahar, K.; Lebouvier, T.; Laviña, B.; Gouveia, L.; et al. Data Descriptor: Single-cell RNA sequencing of mouse brain and lung vascular and vessel-associated cell types. Sci. Data 2018, 5, 180160. [CrossRef]

42. Kuhnert, F.; Mancuso, M.R.; Shamloo, A.; Wang, H.T.; Choksi, V.; Florek, M.; Su, H.; Fruttiger, M.; Young, W.L.; Heilshorn, S.C.; et al. Essential regulation of CNS angiogenesis by the orphan G protein-coupled receptor GPR124. Science 2010, 330, 985-989. [CrossRef]

43. Anderson, K.D.; Pan, L.; Yang, X.M.; Hughes, V.C.; Walls, J.R.; Dominguez, M.G.; Simmons, M.V.; Burfeind, P.; Xue, Y.; Wei, Y.; et al. Angiogenic sprouting into neural tissue requires Gpr124, an orphan G protein-coupled receptor. Proc. Natl. Acad. Sci. USA 2011, 108, 2807-2812. [CrossRef]

44. Alvarez, J.I.; Dodelet-Devillers, A.; Kebir, H.; Ifergan, I.; Fabre, P.J.; Terouz, S.; Sabbagh, M.; Wosik, K.; Bourbonnière, L.; Bernard, M.; et al. The Hedgehog pathway promotes blood-brain barrier integrity and CNS immune quiescence. Science 2011, 334, 1727-1731. [CrossRef]

45. Géraud, C.; Koch, P.S.; Zierow, J.; Klapproth, K.; Busch, K.; Olsavszky, V.; Leibing, T.; Demory, A.; Ulbrich, F.; Diett, M.; et al. GATA4-dependent organ-specific endothelial differentiation controls liver development and embryonic hematopoiesis. J. Clin. Investig. 2017, 127, 1099-1114. [CrossRef] [PubMed]

46. Desroches-Castan, A.; Tillet, E.; Ricard, N.; Ouarné, M.; Mallet, C.; Belmudes, L.; Couté, Y.; Boillot, O.; Scoazec, J.-Y.; Bailly, S.; et al. Bone Morphogenetic Protein 9 Is a Paracrine Factor Controlling Liver Sinusoidal Endothelial Cell Fenestration and Protecting Against Hepatic Fibrosis. Hepatology 2019, 70, 1392-1408. [CrossRef] [PubMed]

47. Boström, K.I.; Yao, J.; Wu, X.; Yao, Y. Endothelial Cells May Have Tissue-Specific Origins. J. Cell Biol. Histol. $2018,1,104$.

48. Goldman, O.; Han, S.; Hamou, W.; Jodon De Villeroche, V.; Uzan, G.; Lickert, H.; Gouon-Evans, V. Endoderm Generates Endothelial Cells during Liver Development. Stem Cell Rep. 2014, 3, 556-565. [CrossRef]

49. Lotto, J.; Drissler, S.; Cullum, R.; Wei, W.; Setty, M.; Bell, E.M.; Boutet, S.C.; Nowotschin, S.; Kuo, Y.Y.; Garg, V.; et al. Single-Cell Transcriptomics Reveals Early Emergence of Liver Parenchymal and Non-parenchymal Cell Lineages. Cell 2020, 183, 702-716.e14. [CrossRef]

50. Little, D.R.; Gerner-Mauro, K.N.; Flodby, P.; Crandall, E.D.; Borok, Z.; Akiyama, H.; Kimura, S.; Ostrin, E.J.; Chen, J. Transcriptional control of lung alveolar type 1 cell development and maintenance by NK homeobox 2-1. Proc. Natl. Acad. Sci. USA 2019, 116, 20545-20555. [CrossRef]

51. Aird, W.C. Phenotypic heterogeneity of the endothelium: II. Representative vascular beds. Circ. Res. 2007, 100, 174-190. [CrossRef]

52. Hennigs, J.K.; Matuszcak, C.; Trepel, M.; Körbelin, J. Vascular endothelial cells: Heterogeneity and targeting approaches. Cells 2021, 10, 2712. [CrossRef]

53. Chavkin, N.W.; Hirschi, K.K. Single Cell Analysis in Vascular Biology. Front. Cardiovasc. Med. 2020, 7, 1-14. [CrossRef]

54. Den Braanker, H.; van Stigt, A.C.; Kok, M.R.; Lubberts, E.; Bisoendial, R.J. Single-cell RNA sequencing reveals heterogeneity and functional diversity of lymphatic endothelial cells. Int. J. Mol. Sci. 2021, 22, 11976. [CrossRef]

55. Gomez-Salinero, J.M.; Itkin, T.; Rafii, S. Developmental angiocrine diversification of endothelial cells for organotypic regeneration. Dev. Cell 2021, 56, 3042-3051. [CrossRef]

56. Minami, T.; Muramatsu, M.; Kume, T. Organ/tissue-specific vascular endothelial cell heterogeneity in health and disease. Biol. Pharm. Bull. 2019, 42, 1609-1619. [CrossRef]

57. Koch, P.S.; Lee, K.H.; Goerdt, S.; Augustin, H.G. Angiodiversity and organotypic functions of sinusoidal endothelial cells. Angiogenesis 2021, 24, 289-310. [CrossRef]

58. Nolan, D.J.; Ginsberg, M.; Israely, E.; Palikuqi, B.; Poulos, M.G.; James, D.; Ding, B.S.; Schachterle, W.; Liu, Y.; Rosenwaks, Z.; et al. Molecular Signatures of Tissue-Specific Microvascular Endothelial Cell Heterogeneity in Organ Maintenance and Regeneration. Dev. Cell 2013, 26, 204-219. [CrossRef]

59. Sørensen, K.K.; Simon-Santamaria, J.; McCuskey, R.S.; Smedsrød, B. Liver sinusoidal endothelial cells. Compr. Physiol. 2015, 5, 1751-1774. [CrossRef]

60. Wisse, E. An electron microscopic study of the fenestrated endothelial lining of rat liver sinusoids. J. Ultrasructure Res. 1970, 31, 125-150. [CrossRef]

61. Debbaut, C.; Segers, P.; Cornillie, P.; Casteleyn, C.; Dierick, M.; Laleman, W.; Monbaliu, D. Analyzing the human liver vascular architecture by combining vascular corrosion casting and micro-CT scanning: A feasibility study. J. Anat. 2014, $224,509-517$. [CrossRef]

62. Kardon, R.H.; Kessel, R.G. Three-dimensional organization of the hepatic microcirculation in the rodent as observed by scanning electron microscopy of corrosion casts. Gastroenterology 1980, 79, 72-81. [CrossRef]

63. Jiř́ḱ, M.; Tonar, Z.; Králíčková, A.; Eberlová, L.; Mírka, H.; Kochová, P.; Gregor, T.; Hošek, P.; Svobodová, M.; Rohan, E.; et al. Stereological quantification of microvessels using semiautomated evaluation of X-ray microtomography of hepatic vascular corrosion casts. Int. J. Comput. Assist. Radiol. Surg. 2016, 11, 1803-1819. [CrossRef]

64. de Haan, W.; Dheedene, W.; Apelt, K.; Décombas-Deschamps, S.; Vinckier, S.; Verhulst, S.; Conidi, A.; Deffieux, T.; Staring, M.W.; Vandervoort, P.; et al. Endothelial Zeb2 preserves the hepatic angioarchitecture and protects against liver fibrosis. Cardiovasc. Res. 2021, 1-14. [CrossRef]

65. Vidal-Vanaclocha, F.; Barberá-Guillem, E. Fenestration patterns in endothelial cells of rat liver sinusoids. J. Ultrastruct. Res. Mol. Struct. Res. 1985, 90, 115-123. [CrossRef] 
66. Barberá-Guillem, E.; Rocha, M.; Alvarez, A.; Vidal-Vanaclocha, F. Differences in the lectin-binding patterns of the periportal and perivenous endothelial domains in the liver sinusoids. Hepatology 1991, 14, 131-139. [CrossRef]

67. Wisse, E.; de Zanger, R.B.; Charels, K.; van der Smissen, P.; McCuskey, R.S. The liver sieve: Considerations concerning the structure and function of endothelial fenestrae, the sinusoidal wall and the space of disse. Hepatology 1985, 5, 683-692. [CrossRef] [PubMed]

68. Coppiello, G.; Collantes, M.; Sirerol-Piquer, M.S.; Vandenwijngaert, S.; Schoors, S.; Swinnen, M.; Vandersmissen, I.; Herijgers, P.; Topal, B.; Van Loon, J.; et al. Meox2/Tcf15 heterodimers program the heart capillary endothelium for cardiac fatty acid uptake. Circulation 2015, 131, 815-826. [CrossRef] [PubMed]

69. Daneman, R.; Zhou, L.; Agalliu, D.; Cahoy, J.D.; Kaushal, A.; Barres, B.A. The Mouse Blood-Brain Barrier Transcriptome: A New Resource for Understanding the Development and Function of Brain Endothelial Cells. PLoS ONE 2010, 5, e13741. [CrossRef] [PubMed]

70. Géraud, C.; Schledzewski, K.; Demory, A.; Klein, D.; Kaus, M.; Peyre, F.; Sticht, C.; Evdokimov, K.; Lu, S.; Schmieder, A.; et al. Liver sinusoidal endothelium: A microenvironment-dependent differentiation program in rat including the novel junctional protein liver endothelial differentiation-associated protein-1. Hepatology 2010, 52, 313-326. [CrossRef]

71. Khan, S.; Taverna, F.; Rohlenova, K.; Treps, L.; Geldhof, V.; De Rooij, L.; Sokol, L.; Pircher, A.; Conradi, L.C.; Kalucka, J.; et al. EndoDB: A database of endothelial cell transcriptomics data. Nucleic Acids Res. 2019, 47, D736-D744. [CrossRef]

72. Elvevold, K.; Smedsrød, B.; Martinez, I. The liver sinusoidal endothelial cell: A cell type of controversial and confusing identity. Am. J. Physiol. Gastrointest. Liver Physiol. 2008, 294, G391-G400. [CrossRef]

73. Lalor, P.F.; Lai, W.K.; Curbishley, S.M.; Shetty, S.; Adams, D.H. Human hepatic sinusoidal endothelial cells can be distinguished by expression of phenotypic markers related to their specialised functions in vivo. World J. Gastroenterol. 2006, 12, 5429-5439. [CrossRef]

74. Ramachandran, P.; Dobie, R.; Wilson-Kanamori, J.R.; Dora, E.F.; Henderson, B.E.P.; Luu, N.T.; Portman, J.R.; Matchett, K.P.; Brice, M.; Marwick, J.A.; et al. Resolving the fibrotic niche of human liver cirrhosis at single-cell level. Nature 2019, 575, 512-518. [CrossRef]

75. Miller, S.; Walker, S.W.; Arthur, J.R.; Lewin, M.H.; Pickard, K.; Nicol, F.; Howie, A.F.; Beckett, G.J. Selenoprotein expression in endothelial cells from different human vasculature and species. Biochim. Biophys. Acta Mol. Basis Dis. 2002, 1588, 85-93. [CrossRef]

76. Soroush, F.; Tang, Y.; Mustafa, O.; Sun, S.; Yang, Q.; Kilpatrick, L.E.; Kiani, M.F. Neutrophil-endothelial interactions of murine cells is not a good predictor of their interactions in human cells. FASEB J. 2020, 34, 2691-2702. [CrossRef]

77. Ramachandran, P.; Matchett, K.P.; Dobie, R.; Wilson-Kanamori, J.R.; Henderson, N.C. Single-cell technologies in hepatology: New insights into liver biology and disease pathogenesis. Nat. Rev. Gastroenterol. Hepatol. 2020, 17, 457-472. [CrossRef]

78. Kalucka, J.; de Rooij, L.P.M.H.; Goveia, J.; Rohlenova, K.; Dumas, S.J.; Meta, E.; Conchinha, N.V.; Taverna, F.; Teuwen, L.A.; Veys, K.; et al. Single-Cell Transcriptome Atlas of Murine Endothelial Cells. Cell 2020, 180, 764.e20-779.e20. [CrossRef]

79. Vanlandewijck, M.; He, L.; Mäe, M.A.; Andrae, J.; Ando, K.; Del Gaudio, F.; Nahar, K.; Lebouvier, T.; Laviña, B.; Gouveia, L.; et al. A molecular atlas of cell types and zonation in the brain vasculature. Nature 2018, 554, 475-480. [CrossRef]

80. Aizarani, N.; Saviano, A.; Sagar; Mailly, L.; Durand, S.; Herman, J.S.; Pessaux, P.; Baumert, T.F.; Grün, D. A human liver cell atlas reveals heterogeneity and epithelial progenitors. Nature 2019, 572, 199-204. [CrossRef]

81. Halpern, K.B.; Shenhav, R.; Massalha, H.; Toth, B.; Egozi, A.; Massasa, E.E.; Medgalia, C.; David, E.; Giladi, A.; Moor, A.E.; et al. Paired-cell sequencing enables spatial gene expression mapping of liver endothelial cells. Nat. Biotechnol. 2018, 36, 962. [CrossRef] [PubMed]

82. Su, T.; Yang, Y.; Lai, S.; Jeong, J.; Jung, Y.; McConnell, M.; Utsumi, T.; Iwakiri, Y. Single-Cell Transcriptomics Reveals Zone-Specific Alterations of Liver Sinusoidal Endothelial Cells in Cirrhosis. Cell. Mol. Gastroenterol. Hepatol. 2021, 11, 1139-1161. [CrossRef] [PubMed]

83. Xiong, X.; Kuang, H.; Ansari, S.; Liu, T.; Gong, J.; Wang, S.; Zhao, X.-Y.; Ji, Y.; Li, C.; Guo, L.; et al. Landscape of intercellular crosstalk in healthy and NASH liver revealed by single-cell secretome gene analysis. Mol. Cell 2019, 75, 644-660. [CrossRef] [PubMed]

84. Rhee, S.; Paik, D.T.; Yang, J.Y.; Nagelberg, D.; Williams, I.; Tian, L.; Roth, R.; Chandy, M.; Ban, J.; Belbachir, N.; et al. Endocardial/endothelial angiocrines regulate cardiomyocyte development and maturation and induce features of ventricular non-compaction. Eur. Heart J. 2021, 42, 4264-4276. [CrossRef]

85. Jiron Tamburini, B.A.; Finlon, J.M.; Gillen, A.E.; Kriss, M.S.; Riemondy, K.A.; Fu, R.; Schuyler, R.P.; Hesselberth, J.R.; Rosen, H.R.; Burchill, M.A. Chronic liver disease in humans causes expansion and differentiation of liver lymphatic endothelial cells. Front. Immunol. 2019, 10, 1-14. [CrossRef]

86. Verhulst, S.; van Os, E.A.; De Smet, V.; Eysackers, N.; Mannaerts, I.; van Grunsven, L.A. Gene Signatures Detect Damaged Liver Sinusoidal Endothelial Cells in Chronic Liver Diseases. Front. Med. 2021, 8, 1-14. [CrossRef]

87. Burchill, M.A.; Finlon, J.M.; Goldberg, A.R.; Gillen, A.E.; Dahms, P.A.; McMahan, R.H.; Tye, A.; Winter, A.B.; Reisz, J.A.; Bohrnsen, E.; et al. Oxidized Low-Density Lipoprotein Drives Dysfunction of the Liver Lymphatic System. Cell. Mol. Gastroenterol. Hepatol. 2021, 11, 573-595. [CrossRef]

88. Koenitzer, J.R.; Wu, H.; Atkinson, J.J.; Brody, S.L.; Humphreys, B.D. Single-nucleus RNA-sequencing profiling of mouse lung reduced dissociation bias and improved rare cell-type detection compared with single-cell RNA sequencing. Am. J. Respir. Cell Mol. Biol. 2020, 63, 739-747. [CrossRef] 
89. Wolfien, M.; Galow, A.M.; Müller, P.; Bartsch, M.; Brunner, R.M.; Goldammer, T.; Wolkenhauer, O.; Hoeflich, A.; David, R. Single nuclei sequencing of entire mammalian hearts: Strain-dependent cell-type composition and velocity. Cardiovasc. Res. 2020, 116, 1249-1251. [CrossRef]

90. Wu, H.; Kirita, Y.; Donnelly, E.L.; Humphreys, B.D. Advantages of single-nucleus over single-cell RNA sequencing of adult kidney: Rare cell types and novel cell states revealed in fibrosis. J. Am. Soc. Nephrol. 2019, 30, 23-32. [CrossRef]

91. Yamada, S.; Nomura, S. Review of single-cell RNA sequencing in the heart. Int. J. Mol. Sci. 2020, 21, 8345. [CrossRef]

92. Cavalli, M.; Diamanti, K.; Pan, G.; Spalinskas, R.; Kumar, C.; Deshmukh, A.S.; Mann, M.; Sahlén, P.; Komorowski, J.; Wadelius, C. A Multi-Omics Approach to Liver Diseases: Integration of Single Nuclei Transcriptomics with Proteomics and HiCap Bulk Data in Human Liver. Omi. A J. Integr. Biol. 2020, 24, 180-194. [CrossRef]

93. Guilliams, M.; Bonnardel, J.; Haest, B.; Vanderborght, B.; Wagner, C.; Remmerie, A.; Bujko, A.; Martens, L.; Thoné, T.; Browaeys, R.; et al. Spatial proteogenomics reveals distinct and evolutionarily conserved hepatic macrophage niches. Cell 2022, 185, 1-18. [CrossRef]

94. Moncada, R.; Barkley, D.; Wagner, F.; Chiodin, M.; Devlin, J.C.; Baron, M.; Hajdu, C.H.; Simeone, D.M.; Yanai, I. Integrating microarray-based spatial transcriptomics and single-cell RNA-seq reveals tissue architecture in pancreatic ductal adenocarcinomas. Nat. Biotechnol. 2020, 38, 333-342. [CrossRef]

95. Hou, X.; Yang, Y.; Li, P.; Zeng, Z.; Hu, W.; Zhe, R.; Liu, X.; Tang, D.; Ou, M.; Dai, Y. Integrating Spatial Transcriptomics and Single-Cell RNA-seq Reveals the Gene Expression Profling of the Human Embryonic Liver. Front. Cell Dev. Biol. 2021, 9, 1-14. [CrossRef]

96. Inverso, D.; Shi, J.; Lee, K.H.; Jakab, M.; Ben-Moshe, S.; Kulkarni, S.R.; Schneider, M.; Wang, G.; Komeili, M.; Vélez, P.A.; et al. A spatial vascular transcriptomic, proteomic, and phosphoproteomic atlas unveils an angiocrine Tie-Wnt signaling axis in the liver. Dev. Cell 2021, 56, 1677.e10-1693.e10. [CrossRef]

97. Andueza, A.; Kumar, S.; Kim, J.; Kang, D.-W.; Mumme, H.L.; Perez, J.I.; Villa-Roel, N.; Jo, H. Endothelial Reprogramming by Disturbed Flow Revealed by Single-Cell RNA and Chromatin Accessibility Study. Cell Rep. 2020, 33, 108491. [CrossRef]

98. Cao, J.; Cusanovich, D.A.; Ramani, V.; Aghamirzaie, D.; Pliner, A.; Hill, H.; Daza, A.J.; McFaline-Figueroa, R.M.; Packer, J.L.; Christiansen, S.; et al. Joint profiling of chromatin accessibility and gene expression in thousands of single cells. Science 2018, 361, 1380-1385. [CrossRef]

99. Muto, Y.; Wilson, P.C.; Ledru, N.; Wu, H.; Dimke, H.; Waikar, S.S.; Humphreys, B.D. Single cell transcriptional and chromatin accessibility profiling redefine cellular heterogeneity in the adult human kidney. Nat. Commun. 2021, 12, 2190. [CrossRef]

100. Sabbagh, M.F.; Heng, J.S.; Luo, C.; Castanon, R.G.; Nery, J.R.; Rattner, A.; Goff, L.A.; Ecker, J.R.; Nathans, J. Transcriptional and epigenomic landscapes of CNS and non-CNS vascular endothelial cells. eLife 2018, 7, 1-44. [CrossRef]

101. Schlereth, K.; Weichenhan, D.; Bauer, T.; Heumann, T.; Giannakouri, E.; Lipka, D.; Jaeger, S.; Schlesner, M.; Aloy, P.; Eils, R.; et al The transcriptomic and epigenetic map of vascular quiescence in the continuous lung endothelium. eLife 2018, 7, 1-23. [CrossRef] [PubMed]

102. Chen, T.; Oh, S.; Gregory, S.; Shen, X.; Diehl, A.M. Single-cell omics analysis reveals functional diversification of hepatocytes during liver regeneration. JCI Insight 2020, 5, 1-16. [CrossRef] [PubMed]

103. Wang, Z.; Cui, M.; Shah, A.M.; Tan, W.; Liu, N.; Duby, B.-R.; Olson, E.N. Cell-Type-Specific Gene Regulatory Networks Underlying Murine Neonatal Heart Regeneration at Single-Cell Resolution. Cell Rep. 2020, 33, 108472. [CrossRef]

104. Marx, V. A dream of single-cell proteomics. Nat. Methods 2019, 16, 809-812. [CrossRef] [PubMed]

105. Yan, F.; Powell, D.R.; Curtis, D.J.; Wong, N.C. From reads to insight: A hitchhiker's guide to ATAC-seq data analysis. Genome Biol. 2020, 21, 1-16. [CrossRef] [PubMed]

106. Marcu, R.; Choi, Y.J.; Xue, J.; Fortin, C.L.; Wang, Y.; Nagao, R.J.; Xu, J.; MacDonald, J.W.; Bammler, T.K.; Murry, C.E.; et al. Human Organ-Specific Endothelial Cell Heterogeneity. iScience 2018, 4, 20-35. [CrossRef] [PubMed]

107. De Haan, W.; Øie, C.; Benkheil, M.; Dheedene, W.; Vinckier, S.; Coppiello, G.; Aranguren, X.L.; Beerens, M.; Jaekers, J.; Topal, B.; et al. Unraveling the transcriptional determinants of liver sinusoidal endothelial cell specialization. Am. J. Physiol. Gastrointest. Liver Physiol. 2020, 318, G803-G815. [CrossRef] [PubMed]

108. Jambusaria, A.; Hong, Z.; Zhang, L.; Srivastava, S.; Jana, A.; Toth, P.T.; Dai, Y.; Malik, A.B.; Rehman, J. Endothelial heterogeneity across distinct vascular beds during homeostasis and inflammation. eLife 2020, 9, 1-32. [CrossRef]

109. Arai, T.; Sakurai, T.; Kamiyoshi, A.; Ichikawa-Shindo, Y.; Iinuma, N.; Iesato, Y.; Koyama, T.; Yoshizawa, T.; Uetake, R.; Yamauchi, A.; et al. Induction of LYVE-1/stabilin-2-positive liver sinusoidal endothelial-like cells from embryoid bodies by modulation of adrenomedullin-RAMP2 signaling. Peptides 2011, 32, 1855-1865. [CrossRef]

110. Gage, B.K.; Liu, J.C.; Innes, B.T.; MacParland, S.A.; McGilvray, I.D.; Bader, G.D.; Keller, G.M. Generation of Functional Liver Sinusoidal Endothelial Cells from Human Pluripotent Stem-Cell-Derived Venous Angioblasts. Cell Stem Cell 2020, 27, 254-269.e9. [CrossRef]

111. Nonaka, H.; Watabe, T.; Saito, S.; Miyazono, K.; Miyajima, A. Development of stabilin2+ endothelial cells from mouse embryonic stem cells by inhibition of TGF $\beta$ /activin signaling. Biochem. Biophys. Res. Commun. 2008, 375, 256-260. [CrossRef]

112. De Smedt, J.; van Os, E.A.; Talon, I.; Ghosh, S.; Toprakhisar, B.; Furtado Madeiro Da Costa, R.; Zaunz, S.; Vazquez, M.A.; Boon, R.; Baatsen, P.; et al. PU.1 drives specification of pluripotent stem cell-derived endothelial cells to LSEC-like cells. Cell Death Dis. 2021, 12, 1-18. [CrossRef] 
113. Shahani, T.; Covens, K.; Lavend'homme, R.; Jazouli, N.; Sokal, E.; Peerlinck, K.; Jacquemin, M. Human liver sinusoidal endothelial cells but not hepatocytes contain factor VIII. J. Thromb. Haemost. 2014, 12, 36-42. [CrossRef]

114. Zapotoczny, B.; Szafranska, K.; Kus, E.; Braet, F.; Wisse, E.; Chlopicki, S.; Szymonski, M. Tracking Fenestrae Dynamics in Live Murine Liver Sinusoidal Endothelial Cells. Hepatology 2019, 69, 876-888. [CrossRef]

115. Wijesekara, P.; Ng, W.H.; Feng, M.; Ren, X. Bioengineering the innate vasculature of complex organs: What have we learned so far. Curr. Opin. Organ Transplant. 2018, 23, 657-663. [CrossRef]

116. Vargas-Valderrama, A.; Messina, A.; Mitjavila-Garcia, M.T.; Guenou, H. The endothelium, a key actor in organ development and hPSC-derived organoid vascularization. J. Biomed. Sci. 2020, 27, 1-13. [CrossRef]

117. Tambe, D.T.; Croutelle, U.; Trepat, X.; Park, C.Y.; Kim, J.H.; Millet, E.; Butler, J.P.; Fredberg, J.J. Monolayer Stress Microscopy: Limitations, Artifacts, and Accuracy of Recovered Intercellular Stresses. PLoS ONE 2013, 8, e55172. [CrossRef]

118. Cucullo, L.; Hossain, M.; Puvenna, V.; Marchi, N.; Janigro, D. The role of shear stress in Blood-Brain Barrier endothelial physiology. BMC Neurosci. 2011, 12, 40. [CrossRef]

119. Wang, C.; Li, J.; Sinha, S.; Peterson, A.; Grant, G.A.; Yang, F. Mimicking brain tumor-vasculature microanatomical architecture via co-culture of brain tumor and endothelial cells in 3D hydrogels. Biomaterials 2019, 202, 35-44. [CrossRef]

120. Reinitz, A.; DeStefano, J.; Ye, M.; Wong, A.D.; Searson, P.C. Human brain microvascular endothelial cells resist elongation due to shear stress. Microvasc. Res. 2015, 99, 8-18. [CrossRef]

121. Birukov, K.G.; Jacobson, J.R.; Flores, A.A.; Ye, S.Q.; Birukova, A.A.; Verin, A.D.; Garcia, J.G.N. Magnitude-dependent regulation of pulmonary endothelial cell barrier function by cyclic stretch. Am. J. Physiol.—Lung Cell. Mol. Physiol. 2003, 285, 785-797. [CrossRef] [PubMed]

122. Yamamoto, K.; Imamura, H.; Ando, J. Shear stress augments mitochondrial atp generation that triggers atp release and Ca ${ }^{2+}$ signaling in vascular endothelial cells. Am. J. Physiol.-Hear. Circ. Physiol. 2018, 315, H1477-H1485. [CrossRef] [PubMed]

123. Ito, S.; Suki, B.; Kume, H.; Numaguchi, Y.; Ishii, M.; Iwaki, M.; Kondo, M.; Naruse, K.; Hasegawa, Y.; Sokabe, M. Actin cytoskeleton regulates stretch-activated $\mathrm{Ca}^{2+}$ influx in human pulmonary microvascular endothelial cells. Am. J. Respir. Cell Mol. Biol. 2010, 43, 26-34. [CrossRef] [PubMed]

124. Merna, N.; Wong, A.K.; Barahona, V.; Llanos, P.; Kunar, B.; Palikuqi, B.; Ginsberg, M.; Rafii, S.; Rabbany, S.Y. Laminar shear stress modulates endothelial luminal surface stiffness in a tissue-specific manner. Microcirculation 2018, 25, e12455. [CrossRef]

125. Bacci, C.; Wong, V.; Barahona, V.; Merna, N. Cardiac and lung endothelial cells in response to fluid shear stress on physiological matrix stiffness and composition. Microcirculation 2021, 28, e12659. [CrossRef]

126. Mitra, D.; Jaffe, E.A.; Weksler, B.; Hajjar, K.A.; Soderland, C.; Laurence, J. Thrombotic thrombocytopenic purpura and sporadic hemolytic-uremic syndrome plasmas induce apoptosis in restricted lineages of human microvascular endothelial cells. Blood 1997, 89, 1224-1234. [CrossRef]

127. Bartoszewski, R.; Moszyńska, A.; Serocki, M.; Cabaj, A.; Polten, A.; Ochocka, R.; Dell'Italia, L.; Bartoszewska, S.; Króliczewski, J.; Dabrowski, M.; et al. Primary endothelial-specific regulation of hypoxiainducible factor (HIF)-1 and HIF-2 and their target gene expression profiles during hypoxia. FASEB J. 2019, 33, 7929-7941. [CrossRef]

128. Galie, P.A.; Van Oosten, A.; Chen, C.S.; Janmey, P.A. Application of multiple levels of fluid shear stress to endothelial cells plated on polyacrylamide gels. Lab Chip 2015, 15, 1205-1212. [CrossRef]

129. Hamm, S.; Dehouck, B.; Kraus, J.; Wolburg-Buchholz, K.; Wolburg, H.; Risau, W.; Cecchelli, R.; Engelhardt, B.; Dehouck, M.P. Astrocyte mediated modulation of blood-brain barrier permeability does not correlate with a loss of tight junction proteins from the cellular contacts. Cell Tissue Res. 2004, 315, 157-166. [CrossRef]

130. Castro Dias, M.; Coisne, C.; Lazarevic, I.; Baden, P.; Hata, M.; Iwamoto, N.; Francisco, D.M.F.; Vanlandewijck, M.; He, L.; Baier, F.A.; et al. Claudin-3-deficient C57BL/6J mice display intact brain barriers. Sci. Rep. 2019, 9, 1-16. [CrossRef]

131. Sabbagh, M.F.; Nathans, J. A genome-wide view of the dedifferentiation of central nervous system endothelial cells in culture. eLife 2020, 9, e51276. [CrossRef]

132. Liguori, G.R.; Liguori, T.T.A.; de Moraes, S.R.; Sinkunas, V.; Terlizzi, V.; van Dongen, J.A.; Sharma, P.K.; Moreira, L.F.P.; Harmsen, M.C. Molecular and Biomechanical Clues from Cardiac Tissue Decellularized Extracellular Matrix Drive Stromal Cell Plasticity. Front. Bioeng. Biotechnol. 2020, 8, 520. [CrossRef]

133. Linville, R.M.; DeStefano, J.G.; Sklar, M.B.; Xu, Z.; Farrell, A.M.; Bogorad, M.I.; Chu, C.; Walczak, P.; Cheng, L.; Mahairaki, V.; et al. Human iPSC-derived blood-brain barrier microvessels: Validation of barrier function and endothelial cell behavior. Biomaterials 2019, 190-191, 24-37. [CrossRef]

134. Cakir, B.; Xiang, Y.; Tanaka, Y.; Kural, M.H.; Parent, M.; Kang, Y.J.; Chapeton, K.; Patterson, B.; Yuan, Y.; He, C.S.; et al. Engineering of human brain organoids with a functional vascular-like system. Nat. Methods 2019, 16, 1169-1175. [CrossRef]

135. Katt, M.E.; Linville, R.M.; Mayo, L.N.; Xu, Z.S.; Searson, P.C. Functional brain-specific microvessels from iPSC-derived human brain microvascular endothelial cells: The role of matrix composition on monolayer formation. Fluids Barriers CNS 2018, 15, 1-12. [CrossRef]

136. Palikuqi, B.; Nguyen, D.H.T.; Li, G.; Schreiner, R.; Pellegata, A.F.; Liu, Y.; Redmond, D.; Geng, F.; Lin, Y.; Gómez-Salinero, J.M.; et al. Adaptable haemodynamic endothelial cells for organogenesis and tumorigenesis. Nature 2020, 585, 426-432. [CrossRef]

137. Kocherova, I.; Bryja, A.; Mozdziak, P.; Volponi, A.A.; Dyszkiewicz-Konwińska, M.; Piotrowska-Kempisty, H.; Antosik, P.; Bukowska, D.; Bruska, M.; Iżycki, D.; et al. Human umbilical vein endothelial cells (HUVECs) co-culture with osteogenic cells: From molecular communication to engineering prevascularised bone grafts. J. Clin. Med. 2019, 8, 1602. [CrossRef] 
138. Baptista, P.M.; Siddiqui, M.M.; Lozier, G.; Rodriguez, S.R.; Atala, A.; Soker, S. The use of whole organ decellularization for the generation of a vascularized liver organoid. Hepatology 2011, 53, 604-617. [CrossRef]

139. Franco, C.A.; Jones, M.L.; Bernabeu, M.O.; Vion, A.C.; Barbacena, P.; Fan, J.; Mathivet, T.; Fonseca, C.G.; Ragab, A.; Yamaguchi, T.P.; et al. Non-canonical wnt signalling modulates the endothelial shear stress flow sensor in vascular remodelling. eLife 2016, 5, 1-22. [CrossRef]

140. Kusuma, S.; Zhao, S.; Gerecht, S. The extracellular matrix is a novel attribute of endothelial progenitors and of hypoxic mature endothelial cells. FASEB J. 2012, 26, 4925-4936. [CrossRef]

141. Pappalardo, A.; Herron, L.; Alvarez Cespedes, D.E.; Abaci, H.E. Quantitative Evaluation of Human Umbilical Vein and Induced Pluripotent Stem Cell-Derived Endothelial Cells as an Alternative Cell Source to Skin-Specific Endothelial Cells in Engineered Skin Grafts. Adv. Wound Care 2021, 10, 490-502. [CrossRef] [PubMed]

142. Lacorre, D.A.; Baekkevold, E.S.; Garrido, I.; Brandtzaeg, P.; Haraldsen, G.; Amalric, F.; Girard, J.P. Plasticity of endothelial cells: Rapid dedifferentiation of freshly isolated high endothelial venule endothelial cells outside the lymphoid tissue microenvironment. Blood 2004, 103, 4164-4172. [CrossRef] [PubMed]

143. Ricard, N.; Bailly, S.; Guignabert, C.; Simons, M. The quiescent endothelium: Signalling pathways regulating organ-specific endothelial normalcy. Nat. Rev. Cardiol. 2021, 18, 565-580. [CrossRef] [PubMed]

144. Molema, G. Heterogeneity in endothelial responsiveness to cytokines, molecular causes, and pharmacological consequences. Semin. Thromb. Hemost. 2010, 36, 246-264. [CrossRef]

145. Dessalles, C.A.; Leclech, C.; Castagnino, A.; Barakat, A.I. Integration of substrate- and flow-derived stresses in endothelial cell mechanobiology. Commun. Biol. 2021, 4, 764. [CrossRef] [PubMed]

146. Iskratsch, T.; Wolfenson, H.; Sheetz, M.P. Appreciating force and shape-the rise of mechanotransduction in cell biology. Nat. Rev. Mol. Cell Biol. 2014, 15, 825-833. [CrossRef]

147. Guimarães, C.F.; Gasperini, L.; Marques, A.P.; Reis, R.L. The stiffness of living tissues and its implications for tissue engineering Nat. Rev. Mater. 2020, 5, 351-370. [CrossRef]

148. Weickenmeier, J.; de Rooij, R.; Budday, S.; Steinmann, P.; Ovaert, T.C.; Kuhl, E. Brain stiffness increases with myelin content. Acta Biomater. 2016, 42, 265-272. [CrossRef]

149. Ford, A.J.; Jain, G.; Rajagopalan, P. Designing a fibrotic microenvironment to investigate changes in human liver sinusoidal endothelial cell function. Acta Biomater. 2015, 24, 220-227. [CrossRef]

150. Bhana, B.; Iyer, R.K.; Chen, W.L.K.; Zhao, R.; Sider, K.L.; Likhitpanichkul, M.; Simmons, C.A.; Radisic, M. Influence of substrate stiffness on the phenotype of heart cells. Biotechnol. Bioeng. 2010, 105, 1148-1160. [CrossRef]

151. Engler, A.J.; Sen, S.; Sweeney, H.L.; Discher, D.E. Matrix Elasticity Directs Stem Cell Lineage Specification. Cell 2006, 126, 677-689. [CrossRef]

152. Fraser, R.; Bowler, L.M.; Day, W.A.; Dobbs, B.; Johnson, H.D.; Lee, D. High perfusion pressure damages the sieving ability of sinusoidal endothelium in rat livers. Br. J. Exp. Pathol. 1980, 61, 222-228.

153. Shah, V.; Haddad, F.G.; Garcia-Cardena, G.; Frangos, J.A.; Mennone, A.; Groszmann, R.J.; Sessa, W.C. Liver sinusoidal endothelial cells are responsible for nitric oxide modulation of resistance in the hepatic sinusoids. J. Clin. Investig. 1997, 100, $2923-2930$. [CrossRef]

154. Rockey, D.C.; Chung, J.J. Reduced nitric oxide production by endothelial cells in cirrhotic rat liver: Endothelial dysfunction in portal hypertension. Gastroenterology 1998, 114, 344-351. [CrossRef]

155. Kohn, J.C.; Zhou, D.W.; Bordeleau, F.; Zhou, A.L.; Mason, B.N.; Mitchell, M.J.; King, M.R.; Reinhart-King, C.A. Cooperative effects of matrix stiffness and fluid shear stress on endothelial cell behavior. Biophys. J. 2015, 108, 471-478. [CrossRef]

156. Bastounis, E.E.; Yeh, Y.T.; Theriot, J.A. Subendothelial stiffness alters endothelial cell traction force generation while exerting a minimal effect on the transcriptome. Sci. Rep. 2019, 9, 1-16. [CrossRef]

157. Sewell-Loftin, M.K.; Brown, C.B.; Baldwin, H.S.; Merryman, W.D. A novel technique for quantifying mouse heart valve leaflet stiffness with atomic force microscopy. J. Heart Valve Dis. 2012, 21, 513-520.

158. Huebsch, N.; Arany, P.R.; Mao, A.S.; Shvartsman, D.; Ali, O.A.; Bencherif, S.A.; Rivera-Feliciano, J.; Mooney, D.J. Harnessing Traction-Mediated Manipulation of the Cell-Matrix Interface to Control Stem Cell Fate. Nat. Mater. 2010, 9, 518-526. [CrossRef]

159. Tyler, W.J. The mechanobiology of brain function. Nat. Rev. Neurosci. 2012, 13, 867-878. [CrossRef]

160. Potjewyd, G.; Kellett, K.A.B.; Hooper, N.M. 3D hydrogel models of the neurovascular unit to investigate blood-brain barrier dysfunction. Neuronal Signal. 2021, 5, 1-24. [CrossRef]

161. Garcia-Polite, F.; Martorell, J.; Del Rey-Puech, P.; Melgar-Lesmes, P.; O’Brien, C.C.; Roquer, J.; Ois, A.; Principe, A.; Edelman, E.R.; Balcells, M. Pulsatility and high shear stress deteriorate barrier phenotype in brain microvascular endothelium. J. Cereb. Blood Flow Metab. 2017, 37, 2614-2625. [CrossRef] [PubMed]

162. Bosworth, A.M.; Kim, H.; O'Grady, K.P.; Richter, I.; Lee, L.; O'Grady, B.J.; Lippmann, E.S. Influence of Substrate Stiffness on Barrier Function in an iPSC-Derived In Vitro Blood-Brain Barrier Model. Cell. Mol. Bioeng. 2022, 15, 31-42. [CrossRef]

163. Mahmoud, M.; Cancel, L.; Tarbell, J.M. Matrix Stiffness Affects Glycocalyx Expression in Cultured Endothelial Cells. Front. Cell Dev. Biol. 2021, 9, 1-8. [CrossRef] [PubMed]

164. Novak, C.; Ballinger, M.N.; Ghadiali, S. Mechanobiology of Pulmonary Diseases: A Review of Engineering Tools to Understand Lung Mechanotransduction. J. Biomech. Eng. 2021, 143, 1-15. [CrossRef] [PubMed] 
165. Iwaki, M.; Ito, S.; Morioka, M.; Iwata, S.; Numaguchi, Y.; Ishii, M.; Kondo, M.; Kume, H.; Naruse, K.; Sokabe, M.; et al. Mechanical stretch enhances IL-8 production in pulmonary microvascular endothelial cells. Biochem. Biophys. Res. Commun. 2009, 389, 531-536. [CrossRef] [PubMed]

166. Aird, W.C. Mechanisms of endothelial cell heterogeneity in health and disease. Circ. Res. 2006, 98, 159-162. [CrossRef]

167. Merna, N.; Fung, K.M.; Wang, J.J.; King, C.R.; Hansen, K.C.; Christman, K.L.; George, S.C. Differential $\beta 3$ Integrin Expression Regulates the Response of Human Lung and Cardiac Fibroblasts to Extracellular Matrix and Its Components. Tissue Eng. Part A 2015, 21, 2195-2205. [CrossRef] [PubMed]

168. Shyy, J.Y.J.; Chien, S. Role of integrins in endothelial mechanosensing of shear stress. Circ. Res. 2002, 91, 769-775. [CrossRef]

169. Collins, C.; Osborne, L.D.; Guilluy, C.; Chen, Z.; O’Brien, E.T., III; Reader, J.S.; Burridge, K.; Superfine, R.; Tzima, E. Haemodynamic and extracellular matrix cues regulate the mechanical phenotype and stiffness of aortic endothelial cells. Nat. Commun. 2014, 5, 3984. [CrossRef]

170. Rickel, A.P.; Sanyour, H.J.; Leyda, N.A.; Hong, Z. Extracellular Matrix Proteins and Substrate Stiffness Synergistically Regulate Vascular Smooth Muscle Cell Migration and Cortical Cytoskeleton Organization. ACS Appl. Bio Mater. 2020, 3, $2360-2369$. [CrossRef]

171. Taha, I.N.; Naba, A. Exploring the extracellular matrix in health and disease using proteomics. Essays Biochem. 2019, 63, 417-432. [CrossRef]

172. Byron, A.; Humphries, J.D.; Humphries, M.J. Defining the extracellular matrix using proteomics. Int. J. Exp. Pathol. 2013, 94, 75-92. [CrossRef]

173. Naba, A.; Clauser, K.R.; Ding, H.; Whittaker, C.A.; Carr, S.A.; Hynes, R.O. The extracellular matrix: Tools and insights for the "omics" era. Matrix Biol. 2016, 49, 10-24. [CrossRef]

174. Shao, X.; Taha, I.N.; Clauser, K.R.; Gao, Y.; Naba, A. MatrisomeDB: The ECM-protein knowledge database. Nucleic Acids Res. 2020, 48, D1136-D1144. [CrossRef]

175. Naba, A.; Gao, Y. MatrisomeDB. Available online: http://matrisomedb.pepchem.org/ (accessed on 19 December 2021).

176. Choudhury, D.; Tun, H.W.; Wang, T.; Naing, M.W. Organ-Derived Decellularized Extracellular Matrix: A Game Changer for Bioink Manufacturing? Trends Biotechnol. 2018, 36, 787-805. [CrossRef]

177. Randles, M.J.; Humphries, M.J.; Lennon, R. Proteomic definitions of basement membrane composition in health and disease. Matrix Biol. 2017, 57-58, 12-28. [CrossRef]

178. Zhang, Y.; He, Y.; Bharadwaj, S.; Hammam, N.; Carnagey, K.; Myers, R.; Atala, A.; Van Dyke, M. Tissue-specific extracellular matrix coatings for the promotion of cell proliferation and maintenance of cell phenotype. Biomaterials 2009, 30, 4021-4028. [CrossRef]

179. Su, J.; Satchell, S.C.; Shah, R.N.; Wertheim, J.A. Kidney decellularized extracellular matrix hydrogels: Rheological characterization and human glomerular endothelial cell response to encapsulation. J. Biomed. Mater. Res. Part A 2018, 106, 2448-2462. [CrossRef]

180. Simsa, R.; Rothenbücher, T.; Gürbüz, H.; Ghosheh, N.; Emneus, J.; Jenndahl, L.; Kaplan, D.L.; Bergh, N.; Serrano, A.M.; Fogelstrand, P. Brain organoid formation on decellularized porcine brain ECM hydrogels. PLoS ONE 2021, 16, 1-22. [CrossRef]

181. Reginensi, D.; Ortiz, D.; Pravia, A.; Burillo, A.; Morales, F.; Morgan, C.; Jimenez, L.; Dave, K.R.; Perez-Pinzon, M.A.; Gittens, R.A Role of Region-Specific Brain Decellularized Extracellular Matrix on in Vitro Neuronal Maturation. Tissue Eng. Part A 2020, 26, 964-978. [CrossRef]

182. Zhang, W.; Du, A.; Liu, S.; Lv, M.; Chen, S. Research progress in decellularized extracellular matrix-derived hydrogels. Regen. Ther. 2021, 18, 88-96. [CrossRef] [PubMed]

183. Zhang, X.; Chen, X.; Hong, H.; Hu, R.; Liu, J.; Liu, C. Decellularized extracellular matrix scaffolds: Recent trends and emerging strategies in tissue engineering. Bioact. Mater. 2022, 10, 15-31. [CrossRef] [PubMed]

184. Baldea, I.; Teacoe, I.; Olteanu, D.E.; Vaida-Voievod, C.; Clichici, A.; Sirbu, A.; Filip, G.A.; Clichici, S. Effects of different hypoxia degrees on endothelial cell cultures-Time course study. Mech. Ageing Dev. 2018, 172, 45-50. [CrossRef] [PubMed]

185. Mendes, R.T.; Nguyen, D.; Stephens, D.; Pamuk, F.; Fernandes, D.; Hasturk, H.; Van Dyke, T.E.; Kantarci, A. Hypoxia-induced endothelial cell responses-possible roles during periodontal disease. Clin. Exp. Dent. Res. 2018, 4, 241-248. [CrossRef]

186. Halder, S.K.; Milner, R. Mild hypoxia triggers transient blood-brain barrier disruption: A fundamental protective role for microglia. Acta Neuropathol. Commun. 2020, 8, 1-13. [CrossRef]

187. Li, L.; Welser, J.V.; Milner, R. Absence of the $\alpha \mathrm{v} \beta 3$ integrin dictates the time-course of angiogenesis in the hypoxic central nervous system: Accelerated endothelial proliferation correlates with compensatory increases in $\alpha 5 \mathrm{~B} 1$ integrin expression. J. Cereb. Blood Flow Metab. 2010, 30, 1031-1043. [CrossRef]

188. Koh, M.Y.; Powis, G. Passing the baton: The HIF switch Mei. Trends Biochem. Sci. 2012, 37, 364-372. [CrossRef]

189. Conway, E.M.; Carmeliet, P. The diversity of endothelial cells: A challenge for therapeutic angiogenesis. Genome Biol. 2004, 5, 207. [CrossRef]

190. Xing-Fei Deng, D.; Tsalenko, A.; Vailaya, A.; Ben-Dor, A.; Kundu, R.; Estay, I.; Tabibiazar, R.; Kincaid, R.; Yakhini, Z.; Bruhn, L.; et al. Differences in vascular bed disease susceptibility reflect differences in gene expression response to atherogenic stimuli. Circ. Res. 2006, 98, 200-208. [CrossRef]

191. Yang, Q.; Wijerathne, H.; Langston, J.C.; Kiani, M.F.; Kilpatrick, L.E. Emerging approaches to understanding microvascular endothelial heterogeneity: A roadmap for developing anti-inflammatory therapeutics. Int. J. Mol. Sci. 2021, 22, 7770. [CrossRef] 
192. Hida, K.; Maishi, N.; Sakurai, Y.; Hida, Y.; Harashima, H. Heterogeneity of tumor endothelial cells and drug delivery. Adv. Drug Deliv. Rev. 2016, 99, 140-147. [CrossRef]

193. Liang, J.; Wang, S.; Zhang, G.; He, B.; Bie, Q.; Zhang, B. A New Antitumor Direction: Tumor-Specific Endothelial Cells. Front. Oncol. 2021, 11, 1-15. [CrossRef]

194. Molema, G. Design of vascular endothelium-specific drug-targeting strategies for the treatment of cancer. Acta Biochim. Pol. 2005, 52, 301-310. [CrossRef]

195. Morofuji, Y.; Nakagawa, S. Drug Development for Central Nervous System Diseases Using In vitro Blood-brain Barrier Models and Drug Repositioning. Curr. Pharm. Des. 2020, 26, 1466-1485. [CrossRef]

196. Hashimoto, Y.; Tachibana, K.; Kondoh, M. Tight junction modulators for drug delivery to the central nervous system. Drug Discov. Today 2020, 25, 1477-1486. [CrossRef]

197. Ian, M.; Williams, W.J.C. Generation of endothelial cells from human pluripotent stem cells: Methods, considerations, and applications. Arterioscler. Thromb. Vasc. Biol. 2019, 39, 1317-1329. [CrossRef]

198. Glassman, P.M.; Myerson, J.W.; Ferguson, L.T.; Kiseleva, R.Y.; Shuvaev, V.V.; Brenner, J.S.; Muzykantov, V.R. Targeting drug delivery in the vascular system: Focus on endothelium. Adv. Drug Deliv. Rev. 2020, 157, 96-117. [CrossRef]

199. Chattopadhyay, R.; Dyukova, E.; Singh, N.K.; Ohba, M.; Mobley, J.A.; Rao, G.N. Vascular endothelial tight junctions and barrier function are disrupted by 15(S)-Hydroxyeicosatetraenoic acid partly via Protein Kinase C e-mediated Zona Occludens-1 Phosphorylation at Threonine 770/772. J. Biol. Chem. 2014, 289, 3148-3163. [CrossRef]

200. Andresen Eguiluz, R.C.; Kaylan, K.B.; Underhill, G.H.; Leckband, D.E. Substrate stiffness and VE-cadherin mechano-transduction coordinate to regulate endothelial monolayer integrity. Biomaterials 2017, 140, 45-57. [CrossRef] 